\title{
Flora da Bahia: Euphorbia (Euphorbiaceae)
}

\section{Daniela Santos Carneiro-Torres ${ }^{1^{*}}$, Otávio Luís Marques da Silva ${ }^{2, a}$ \& Inês Cordeiro ${ }^{2, b}$}

${ }^{1}$ Programa de Pós-graduação em Botânica, Departamento de Ciências Biológicas, Universidade Estadual de Feira de Santana, Feira de Santana, Bahia, Brasil.

2 Programa de Pós-graduação em Biodiversidade Vegetal e Meio Ambiente, Instituto de Botânica, Núcleo de Pesquisa Curadoria do Herbário SP, São Paulo, SP, Brasil.

Resumo - Foram reconhecidas aqui 29 espécies de Euporbia (Euphorbiaceae) no estado da Bahia. São apresentados chave de identificação, descrições, ilustrações e comentários sobre os táxons, bem como mapas de distribuição das espécies no estado.

Palavras-chave adicionais: Euphorbieae, florística, Brasil.

Abstract (Flora of Bahia: Euphorbia (Euphorbiaceae)) - Twenty-nine species of Euphorbia (Euphorbiaceae) from the state of Bahia are recognized here. Key for identification, descriptions, illustrations, and comments about the taxa, as well as distribution maps of the species in the state, are presented.

Additional key words: Euphorbieae, floristics, Brazil.

\section{EUPHORBIACEAE}

Árvores, arbustos, subarbustos, ervas e trepadeiras, prostrados a eretos, monoicos ou dioicos, frequentemente latescentes. Folhas geralmente alternas, às vezes opostas ou verticiladas, simples ou raro compostas, neste caso digitadas, simétricas a assimétricas na base, peninérvias a palmatinérvias, algumas vezes bastante reduzidas; estípulas presentes ou não. Inflorescências do tipo dicásio, tirso, racemo, espiga, glomérulo ou pseudanto, às vezes flores solitárias. Flores diclinas, actinomorfas, geralmente monoclamídeas, mais raro diclamídeas; pétalas e sépalas unidas ou livres; disco nectarífero frequentemente presente, segmentado ou inteiro; estames (1-)3-20(-400), livres ou unidos; anteras 2tecas, rimosas; grãos de pólen frequentemente tricolporados ou inaperturados, tectados ou intectados; gineceu sincárpico, 3-carpelar; estiletes livres ou unidos na porção basal, geralmente divididos; ovário 3locular, placentação axilar; óvulo 1 por lóculo, pêndulo, 2-tegumentado, obturador placentário presente. Frutos frequentemente capsulares, com deiscência explosiva, septicida, septicida-loculicida ou loculicida, raro drupáceo ou bacáceo; semente 1 por lóculo ou raro solitárias no fruto por aborto, frequentemente provida de carúncula (Webster 1994a; Radcliffe-Smith 2001).

Euphorbiaceae conta atualmente com 246 gêneros e cerca de 6.300 espécies, classificadas em quatro subfamílias: Acalyphoideae, Crotonoideae, Cheilosoideae e Euphorbioideae (Chase et al. 2002; Wurdack et al. 2005; Wurdack \& Davis 2009). Estão

\footnotetext{
*Autora para correspondência: dscarneiro@hotmail.com;

aotaviolmarques@gmail.com; bisandona@uol.br

Editor responsável: Alessandro Rapini

Submetido: 26 nov. 2017; aceito: 20 dez. 2017
}

Publicação eletrônica: 28 dez. 2017; versão final: 16 abr. 2018 distribuídas principalmente em regiões tropicais, porém muitos representantes da tribo Euphorbieae ocorrem em áreas temperadas (Webster 1994a,b). No Brasil, Euphorbiaceae está entre as 10 famílias mais representativas de angiospermas, com 934 espécies e 64 gêneros, sendo que 638 espécies são endêmicas (BFG 2015). Na Bahia, são registradas 310 espécies, distribuídas em 41 gêneros, sendo Croton L. (99 espécies), Euphorbia L. (29), Cnidoscolus Pohl (25), Manihot Mill. (22) e Microstachys A.Juss. (11) os mais representativos (BFG 2015).

\section{Euphorbia L.}

Ervas, subarbustos ou mais raramente árvores, monoicos ou raramente dióicos, glabros ou pilosos; látex branco, leitoso. Folhas simples, alternas, tornando-se opostas ou verticiladas junto às inflorescências, simétricas ou assimétricas na base; estípulas ausentes, interpeciolares ou reduzidas a glândulas. Ciátios terminais ou axilares, subtendidos por uma ou duas brácteas (ciatófilos), invólucro actinomorfo a zigomorfo, com 4 ou 5 lobos alternos aos nectários; nectários providos ou não de apêndices. Flores estaminadas aclamídeas, dispostas em 4 ou 5 címulas, com 1-10 flores cada; estame 1, anteras 2tecas, dorsifixas, extrorsas, tecas divergentes, deiscência horizontal. Flores pistiladas aclamídeas, solitárias, no centro do ciátio; estiletes 3, 2-partidos ou raramente inteiros, livres ou unidos na base. Frutos cápsulas, deiscência septicida-loculicida; sementes com testa variavelmente ornamentada, às vezes com camada mucilaginosa, carunculadas ou não.

Euphorbia é o maior gênero de Euphorbiaceae, abrangendo cerca de 2.000 espécies, com distribuição quase cosmopolita, sendo mais diverso em regiões tropicais e subtropicais (Frodin 2004; Horn et al. 2012). A circunscrição do gênero sofreu várias modificações desde Linnaeus (1753), com a 
segregação de vários gêneros, dentre os mais conhecidos Chamaesyce Gray, Poinsettia Graham e Pedilanthus Neck. ex Poit., ou como um único grande gênero, como é atualmente aceito, tendo o ciátio como sinapomorfia morfológica (Horn et al. 2012).

$\mathrm{Na}$ Bahia, são registradas 29 espécies de Euphorbia, ocorrendo em ambientes antropizados, campos de altitude, caatinga, cerrado, bordas de floresta e restinga. Além dessas espécies, outras introduzidas, de valor paisagístico, como E. cotinifolia L. (caracasana), E. cyathophora Murray, E. graminea Jacq., E. leucocephala Lotsy (neve-da-montanha), E. milii Des Moul. (coroa-de-cristo), E. pulcherrima Willd. ex Klotzsch (bico-de-papagaio) e E. tirucalli L. (avelós), são cultivadas como ornamentais e/ou cercas vivas e não são incluídas nesta flora.

\section{Chave para as espécies}

1. Folhas com base assimétrica.

2. Ervas prostradas.

3. Plantas glabras.

4. Ciátios zigomorfos; apêndices dos ciátios desiguais, pubescentes no ápice; 20 flores estaminadas por ciátio

6. E. chamaeclada

4'. Ciátios actinomorfos; apêndices dos ciátios iguais, glabros; 5 flores estaminadas por ciátio

24. E. serpens

3'. Plantas puberulentas ou pubescentes.

5. Ovário e frutos com tricomas apenas ao longo dos septos

21. E. prostrata

5'. Ovário e frutos totalmente cobertos de tricomas.

6. Ciátios actinomorfos; apêndices dos ciátios ausentes ou pouco desenvolvidos

6'. Ciátios zigomorfos; apêndices dos ciátios ausentes ou bem desenvolvidos.

7. Folhas com mancha escura na região mediana; apêndices dos ciátios alvos

28. E. thymifolia

7'. Folhas sem mancha escura na região mediana; apêndices dos ciátios rosados

9. E. dioeca

1. E. adenoptera

2'. Ervas eretas, suberetas, decumbentes a escandentes.

8. Folhas com margens irregularmente a esparsamente serrilhadas a serradas; invólucro dos ciátios turbinado.

9. Ciátios em dicásios glomeruliformes; ovário hirsuto-pubescente

15. E. hirta

9'. Ciátios em dicásios ou monocásios; ovário glabro.

10. Dicásios bastante ramificados, com eixos laterais terminais congestos

16. E. hyssopifolia

10'. Dicásios pouco ramificados, sem eixos laterais congestos

8'. Folhas com margens inteiras, ou serreadas apenas no ápice; invólucro dos ciátios campanulado a hemisférico.

11. Ciátios com invólucro glabro e apêndices iguais.

12. Ramos glabros; limbo foliar linear-lanceolado; ciátios actinomorfos

12'. Ramos pubescentes; limbo foliar oblongo; ciátios zigomorfos

20. E. potentilloides

11'. Ciátios com invólucros hirsuto-velutinos a pubescentes e apêndices desiguais.

13. Apêndices dos ciátios glabros ou com margens ciliadas; estiletes glabros ..... 29. E. viscoides

13'. Apêndices dos ciátios e estiletes pubescentes

26. E. tamanduana

1'. Folhas com base simétrica (atenuada, cuneada ou subcordada) ou plantas áfilas ou com folhas rudimentares.

14. Ciátios zigomorfos com 1 ou 2 nectários.

15. Nectário 1 por ciátio, estipitado, desprovido de apêndice

14. E. heterophylla

15'. Nectários 2(3) por ciátio, não estipitados, com 2 apêndices bilabiados 17. E. insulana

14'. Ciátios actinomorfos, com 4 ou 5 nectários.

16. Ciátios em monocásios, terminais, com brácteas orbiculares.

17. Folhas persistentes; flores estaminadas 7 ou 8 por ciátio; estiletes inteiros

17'. Folhas caducas; flores estaminadas 20 por ciátio; estiletes 2-partidos

16'. Ciátios solitários, geminados, em glomérulos, dicásios ou em umbelas, desprovidos de brácteas orbiculares.

18. Plantas áfilas ou com folhas rudimentares.

19. Cladódios cilíndricos; apêndices dos ciátios ausentes ou, se presentes, denteados ou 3-5partidos.

20. Ervas, ca. 0,3 m alt.; cladódios não verticilados; apêndices dos ciátios 3-5-partidos ...

20’. Subarbustos, 0,3-1,5 m alt.; cladódios verticilados; apêndices dos ciátios ausentes ou elípticos, denteados. 
21. Ciátios sem apêndices

21'. Ciátios com apêndices 27. E. teres

19’. Cladódios 6-8-costados; apêndices dos ciátios inteiros a 2-partidos.

22. Plantas até $0,3 \mathrm{~m}$ alt.; caule 6-costados; apêndices dos ciátios inteiros, elípticos; estiletes 2-partidos

3. E. appariciana

22'. Plantas até $4 \mathrm{~m}$ alt.; caule 6-8-costados; apêndices dos ciátios corniculados; estiletes inteiros.

23. Caule 8-costado

19. E. phosphorea

23'. Caule 6-costado

4. E. attastoma

18'. Plantas com folhas desenvolvidas.

24. Invólucro dos ciátios campanulado.

25. Limbo foliar espatulado; invólucro dos ciátios glabro; flores estaminadas 20 por ciátio

22. E. sarcodes

25'. Limbo foliar linear, oval a elíptico-oblongo; invólucro dos ciátios pubérulo a puberulento; flores estaminadas 30-40 por ciátio.

26. Limbo foliar linear; ciátios em umbelas; nectários 4 por ciátio; apêndices dos ciátios 11- ou 12-partidos

8. E. crossadenia

$26^{\prime}$. Limbo foliar oval a elíptico-oblongo; ciátios solitários a congestos; nectários 5 por ciátio; apêndices dos ciátios 7-9-partidos

18. E. jablonskii

24'. Invólucro dos ciátios turbinado.

27. Ciátios solitários, com apêndices 8- ou 9-partidos

27'. Ciátios em umbelas ou dicásios, com apêndices 2-7-partidos.

28. Limbo foliar orbicular; ciátios em dicásios, com apêndices 2-4-partidos; 5-10 flores estaminadas por ciátio

28'. Limbo foliar lanceolado a linear-lanceolado; ciátios em umbela, com apêndices 5-7-partidos; 15-20 flores estaminadas por ciátio

11. E. goyazensis

1. Euphorbia adenoptera Bertol., Misc. Bot. 3: 20. 1844.

Figura 2.

Ervas prostradas; ramos vináceos a esverdeados, pubescentes. Folhas opostas, membranáceas, actinódromas; limbo elíptico, 4-10 × 2-4,5 mm, ápice obtuso a arredondado, base assimétrica, margens serreadas a inconspicuamente serreadas, face abaxial esparsamente pubescente, a adaxial glabra; pecíolo ca. 1 $\mathrm{mm}$ compr.; estípulas lanceoladas, $0,8-1 \mathrm{~mm}$ compr., inteiras, glabras. Ciátios zigomorfos, solitários a geminados, axilares; pedúnculo $1-2 \mathrm{~mm}$ compr.; invólucro turbinado, $1-1,5 \times 0,5-0,7 \mathrm{~mm}$, pubescente; lobos triangulares, margens inteiras, ciliadas, esverdeados; nectários 4, elipsoidais, verdes a avermelhados; apêndices 4, desiguais, reniformes, glabros, rosados a avermelhados; bractéolas ausentes. Flores estaminadas 4 ou 5 por ciátio, ca. $1,5 \mathrm{~mm}$ compr.; anteras púrpura; pedicelo ca. $0,7 \mathrm{~mm}$ compr. Flores pistiladas $1-1,5 \mathrm{~mm}$ compr.; ovário globoso, $0,5-0,8 \times 0,5-0,8 \mathrm{~mm}$, pubescente; estiletes unidos na base, ramos 2-partidos, patentes, glabros; estigmas capitados; pedicelo $0,6-1 \mathrm{~mm}$ compr. Frutos subglobosos, $1-1,5 \times 1,2-1,4 \mathrm{~mm}$, pubescentes, amarelados a avermelhados; pedicelo $1-1,5 \mathrm{~mm}$ compr., pêndulo sem romper o invólucro; sementes castanhas, ovais, $0,8-1 \times 0,4-0,5 \mathrm{~mm}$, com $4-8$ costelas transversais estreitas, sem carúncula.

Amplamente distribuída, desde o México até a Argentina; no Brasil, ocorre na Bahia, Espírito Santo, Maranhão, Minas Gerais, Pernambuco, Piauí e São Paulo. B5, B6, B7, B/C8, B9, C7, D8, D9, E6, E8, E9,
F6, G4 e G7: áreas antropizadas. Encontrada com flores e/ou frutos o ano todo.

Material selecionado - Bendengó, fev. 2000, A.M. Giulietti \& R.M. Harley 1723 (HUEFS); Cachoeira, jun. 1980, Grupo Pedra do Cavalo 139 (HUEFS); Camaçari, fev. 1982, L.R. Noblick et al. 2556 (HUEFS); Canudos, jun. 2008, F. França et al. 5752 (HUEFS); Casa Nova, fev. 2004, L.P. Queiroz et al. 9128 (HUEFS); Conceição do Coité, jun. 2013, D.N. Carvalho 279 (HUEFS); Feira de Santana, abr. 2010, Silva et al. 25 (HUEFS); Glória, jul. 1995, F.P. Bandeira 210 (HUEFS); Iaçu, jun. 1997, F. França et al. 2302 (HUEFS); Ipecaetá, ago. 1985, L.R. Noblick \& C. Lôbo 4252 (HUEFS); Juazeiro, mar. 2000, M.R. Fonseca et al. 1324 (HUEFS); Malhada, abr. 2001, J.G. Jardim et al. 3420 (HUEFS); Nova Redenção, mar. 2003, L. Senna 150 (HUEFS); Poções, jan. 2009, P.D. Carvalho \& A.A. Conceição 457 (HUEFS); Remanso, fev. 2000, A. Nascimento et al. 242 (HUEFS); Rio de Contas, jan. 2003, R.M. Harley \& A.M. Giulietti 54587 (HUEFS); Salvador, fev. 1980, L.R. Noblick 1683 (HUEFS); Senhor do Bonfim, jul. 2005, P.D. Carvalho et al. 147 (HUEFS); Serra Preta, jul. 1985, L.R. Noblick \& M.J. Lemos 4177 (HUEFS); Tucano, jan. 2006, D. Cardoso \& A. Amadeu 911 (HUEFS).

Euphorbia adenoptera é semelhante a E. thymifolia, quanto ao hábito prostrado, invólucro do ciátio e ovário pubescentes, porém difere dela por apresentar apêndices bem desenvolvidos e, na maturação, o fruto é pendulo, sem romper o invólucro, enquanto em $E$. thymifolia, os apêndices estão ausentes ou são pouco desenvolvidos e a maturação do fruto rompe o invólucro. Outra espécie semelhante é E. dioeca, da qual difere pela cor dos apêndices (brancos em $E$. dioeca vs. rosados a avermelhados em E. adenoptera) e ausência de uma mancha mais escura na região mediana da face adaxial das folhas. 
2. Euphorbia alsinifolia Boiss., Cent. Euphorb.: 16. 1860.

Figura 2.

Ervas eretas, até $0,3 \mathrm{~m}$ alt.; ramos esverdeados a levemente vináceos, pubescentes. Folhas opostas, membranáceas, actinódromas; limbo oblongo, 3-5 $\times$ 2-3 mm, ápice mucronado, base assimétrica, margens inteiras, faces abaxial e adaxial glabras; pecíolo ca. 1 $\mathrm{mm}$ compr.; estípulas triangulares, ca. 0,4 mm compr., inteiras, ciliadas. Ciátios zigomorfos, solitários, axilares; pedúnculo 1-3 $\mathrm{mm}$ compr.; invólucro hemisférico a campanulado, 1-2 × 0,7-0,1 mm, glabro; lobos estreito-triangulares, margens inteiras, pubescentes; nectários 4, elipsoidais, verdes a amareloesverdeados; apêndices 4, iguais, obovados, irregularmente 3-lobados, glabros, brancos; bractéolas lineares, ca. $1 \mathrm{~mm}$ compr., pubescentes. Flores estaminadas 20 por ciátio, ca. $1 \mathrm{~mm}$ compr.; anteras amarelas; pedicelo ca. 0,6 $\mathrm{mm}$ compr. Flores pistiladas $2-3 \mathrm{~mm}$ compr.; ovário globoso, $0,5-0,7 \times$ 0,5-0,7 mm, glabro; estiletes unidos na base, ramos 2partidos, patentes, glabros; estigmas capitados. Frutos globosos, 1-1,5 × 0,9-1,5 mm, glabros, amarelados a amarelo-esverdeados; pedicelo 1-1,3 mm compr.; sementes castanhas, ovais, ca. $1 \times 0,5 \mathrm{~mm}$, costelas não vistas, sem carúncula ausente.

Restrita à Bahia. C5, C7 e D5: caatinga, sobre solo arenoso. Encontrada com flores e com frutos de maio a junho.

Material selecionado - Barra, maio 2010, L.P. Queiroz et al. 14663 (HUEFS); Juazeiro, maio 1985, G. Fotius et al. 4019 (HUEFS); Xique-Xique, jun. 1996, M.L. Guedes et al. PCD 3021 (HUEFS).

Distingue-se das demais espécies de Euphorbia da Bahia pelo hábito ereto, ciátios elipsoides, com apêndices petaloides iguais entre si e bractéolas lineares e pubescentes.

3. Euphorbia appariciana Rizzini, Revista Brasil. Biol. 49(4): 992. 1989.

Figuras $1 \mathrm{~A}-\mathrm{M}$ e 2.

Ervas eretas a suberetas, até $0,3 \mathrm{~m}$ alt., cactiformes; cladódios verticilados, suculentos, eretos, articulados, 6-costados, verdes com ápices vináceos, glabros, áfilos; estípulas triangulares, ca. 1 mm compr., agudas, glabras. Ciátios actinomorfos, monoclinos a diclinos, solitários a geminados, terminais, sésseis a subsésseis; brácteas lanceoladas a oval-oblongas, 1,5-2 $\mathrm{mm}$ compr., fimbriadas; invólucro hemisférico, 1-2 × 1-1,6 mm, glabro; lobos oval-lanceolados, fimbriados, glabros, amareloesverdeados; nectários 5, transversalmente elípticos, branco-amarelados; apêndices 5, inteiros, elípticos, crenulados, amarelo-esverdeados, glabros; bractéolas lanceoladas, pubescentes. Flores estaminadas 20-25 por ciátio, 2-2,5 mm compr.; pedicelo 1-1,5 $\mathrm{mm}$ compr. Flores pistiladas $1,5-2 \mathrm{~mm}$ compr.; ovário subgloboso, ca. $1 \times 1,5 \mathrm{~mm}$, glabro; estiletes unidos na base, ramos 2-partidos, patentes; estigmas obtusos; pedicelo 0,5-1 mm compr. Frutos subglobosos, 2-3,7 $\times 2-4 \mathrm{~mm}$, glabros, avermelhados; pedicelo ca. $2 \mathrm{~mm}$ compr.; sementes castanho-escuras, ovais a globosas, ca. $2 \times 2 \mathrm{~mm}$, sem ornamentação, carúncula inconspícua.

Restrita ao norte da Chapada Diamantina. C6, D6, D7 e E6: campo rupestre e mata estacional, sobre solos arenosos, entre rochas areníticas. Encontrada com flores ou frutos entre julho e novembro.

Material selecionado - Jacobina, jul. 1996, H.P. Bautista et al. PCD 3416 (ALCB, CEPEC, HUEFS); Minas do Mimoso, mar. 1974, R.M. Harley 17011 (CEPEC); Morro do Chapéu, mar. 1977, R.M. Harley 19202 (CEPEC, IPA); Seabra, jan. 2003, F. França et al. 4064 (HUEFS).

Euphorbia appariciana é diferenciada das espécies cactiformes E. phosphorea e E. gymnoclada, da Chapada Diamantina, por apresentar ramos cactiformes verticilados com cladódios 6-costados e ciátios monoclinos a diclinos, sendo que os ciátios estaminados possuem a flor pistilada rudimentar e os ciátios pistilados possuem flores estaminadas com anteras vazias. Euphorbia gymnoclada possui cladódios não costados e ciátios monoclinos e $E$. phosphorea apresenta cladódios 8-costados e ciátios monoclinos. Outra espécie cactiforme é E. attastoma, que possui os ciátios em glomérulos, os apêndices 2partidos e corniculados, enquanto E. appariciana possui ciátios solitários a geminados e apêndices inteiros.

\section{Euphorbia attastoma Rizzini, Revista Brasil. Biol. 49: 987.1989.}

Figura 3.

Arbustos eretos, ramificados, 1-3 m alt., cactiformes; cladódios suculentos, 6-costados, verdes a levemente cinéreos, glabros, afilos; estípulas não observadas. Ciátios actinomorfos, monoclinos, em glomérulos, axilares; pedúnculo 1-2 $\mathrm{mm}$ compr.; brácteas triangulares, $1,2-1,5 \times 1,3-1,8 \mathrm{~mm}$, ápice agudo, glabras; invólucro hemisférico, 6-7 × 6-7 mm, glabro, verde ou vináceo; lobos obovados, fimbriados, glabros, vináceos; nectários 5, elípticos, verdes; apêndices 2-partidos, corniculados, ápices encurvados, glabros, esbranquiçados; bractéolas flabeliformes, fimbriadas, glabras. Flores estaminadas 12-16 por ciátio, 0,5-2 mm compr., subsésseis. Flores pistiladas 6-7 mm compr.; ovário globoso, ca. $2 \times 2 \mathrm{~mm}$ compr., glabro; estiletes unidos na base, ramos inteiros, eretos; estigmas obtusos; pedicelo 2,5-3 mm compr. Frutos globosos, ca. $4 \times 5 \mathrm{~mm}$, glabros, vináceos; sementes castanhas, globosas, 2,3-3 × 1,8-2,5 mm, sem ornamentação, com carúncula.

Era referida apenas para Minas Gerais (Flora do Brasil 2020, em construção), sendo registrada também para o município de Licínio de Almeida. G5: em afloramentos rochosos, com flores e/ou frutos de dezembro a abril.

Material selecionado - Licínio de Almeida, dez. 2012, F. Hurbath 410 (HUNEB). 


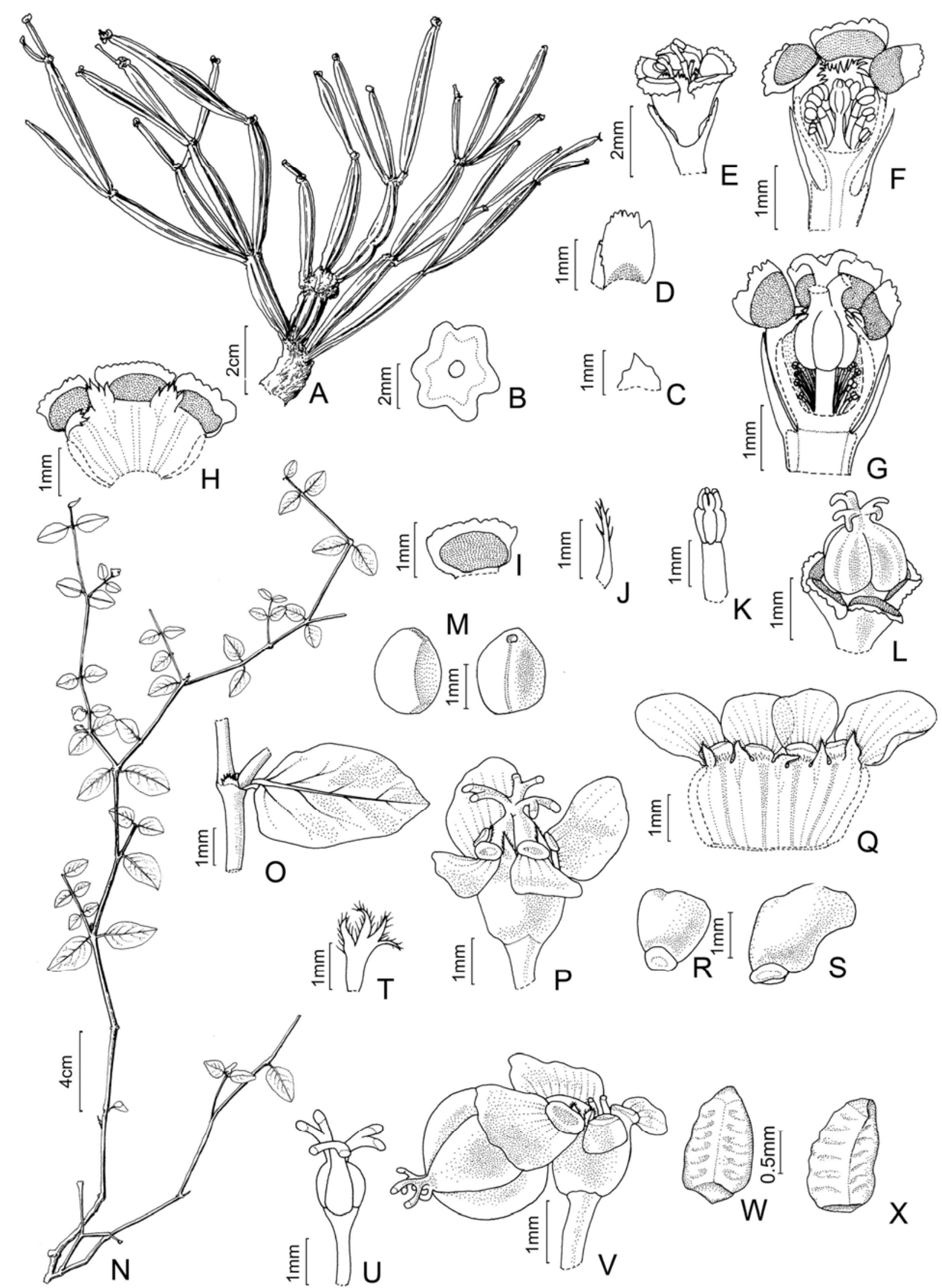

Figura 1. A-M. Euphorbia appariciana: A- hábito; B- cladódio, corte transversal; C- estípula, face adaxial; D- bráctea, face adaxial; E- ciátio; F- ciátio com flor pistilada estéril, corte longitudinal; G- ciátio mostrando fruto, corte longitudinal; H- ciátio, corte longitudinal; I- apêndice e nectário, vista frontal; J- bractéola; K- flor pistilada estéril; L- ciátio com fruto; M- sementes, vistas frontal (à direita) e lateral (à esquerda) (Giulietti PCD 3267). N-X. E. chamaeclada: N- hábito; O- folha e estípula; P- ciátio; Q- ciátio, corte longitudinal; R- nectário e apêndice obovado, vista frontal S- nectário e apêndice pandurado, vista frontal; T- bractéola; $\mathbf{U}$ - flor pistilada; V- ciátio com fruto; W- semente, vista lateral; X- semente, vista frontal (Harley 18980). 


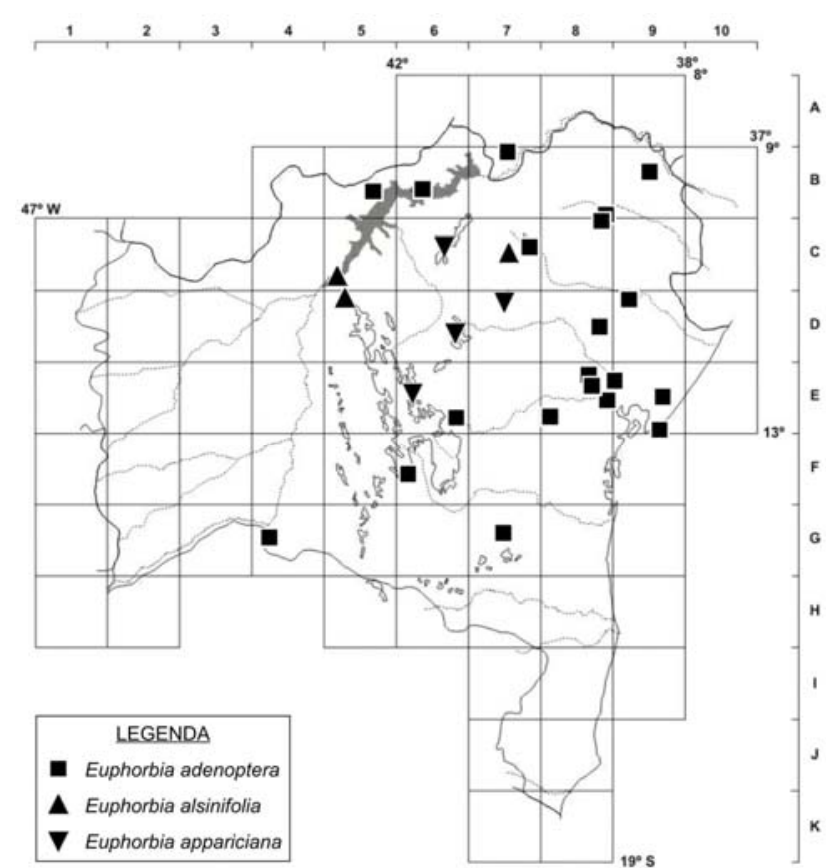

Figura 2. Mapa de distribuição geográfica de Euphorbia adenoptera, E. alsinifolia e E. appariciana no estado da Bahia.

Euphorbia attastoma tem como espécie próxima E. phosphorea Mart., da qual difere por apresentar ramos 6-costados, enquanto E. phosphorea possui ramos 8costados. Além disso, E. attastoma é conhecida apenas para o sudoeste do estado, enquanto E. phosphorea é amplamente distribuída ao longo da caatinga, mata estacional e campo rupestre.

5. Euphorbia bahiensis (Klotzsch \& Garcke) Boiss., Prodr. 15(2): 24. 1862.

Figura 3.

Ervas eretas, ca. 0,5 m alt.; ramos avermelhados; caule glabro ou esparsamente viloso. Folhas opostas, membranáceas; limbo oblongo a elíptico, 10-25 × $15 \mathrm{~mm}$, ápice obtuso a arredondado, base assimétrica, margens planas, inteiras a esparsamente serreadas no ápice, faces abaxial e adaxial esparsamente vilosas; pecíolo 0,5-1 mm compr.; estípulas triangulares, 1-1,5 mm compr., inteiras, pilosas. Ciátios actinomorfos, em dicásios, axilares ou terminais, pouco ramificados; pedúnculo 0,5-1 $\mathrm{mm}$ compr.; invólucro turbinado, 11,5 $\times$ 0,5-1 mm, glabro; lobos triangulares, margens inteiras, ciliadas, amarelo-esverdeados; nectários 4, elipsoides, amarelos; apêndices 4, iguais, reniformes, glabros, brancos a rosados; bractéolas fimbriadas, pilosas. Flores estaminadas ca. 20 por ciátio, 1-1,5 mm compr.; anteras amarelas; pedicelo ca. 0,5-1 mm compr. Flores pistiladas $1-1,5 \mathrm{~mm}$ compr.; ovário globoso, $0,3-0,5 \times 0,3-0,5 \mathrm{~mm}$, glabro; estiletes unidos na base, ramos 2-partidos, eretos; estigmas indiferenciados; pedicelo 0,5-1 $\mathrm{mm}$ compr. Frutos globosos, 2,5-3 × 2,5-3 $\mathrm{mm}$, glabros, verdeamarelados ou avermelhados; pedicelo 1,5-2 $\mathrm{mm}$ compr.; sementes castanhas, globosas, 1,3-1,5 × 1-1,1 $\mathrm{mm}$, com 4 costelas transversais estreitas.

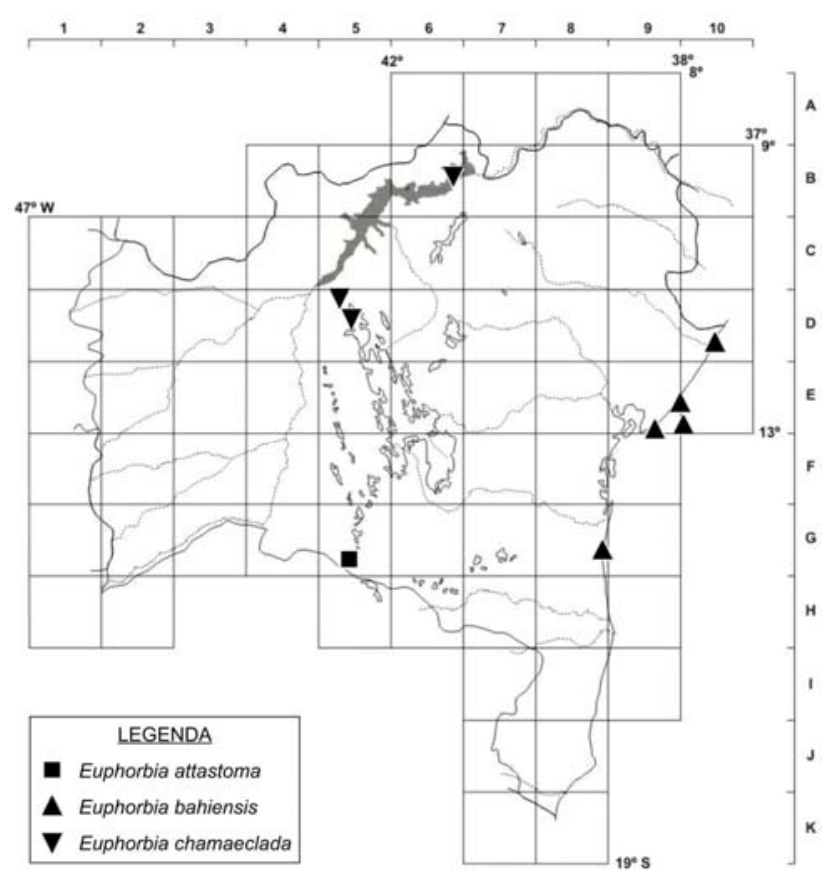

Figura 3. Mapa de distribuição geográfica de Euphorbia attastoma, E. bahiensis e E. chamaeclada no estado da Bahia.

Amplamente distribuída, desde a Costa Rica até o Brasil; no Brasil, ocorre na Bahia, Ceará, Espírito Santo, Maranhão, Pará, Paraíba, Paraná, Piauí, Rio de Janeiro, São Paulo e Sergipe. D10, E/F9, E9/10 e G8: restinga. Encontrada com flores e frutos durante o ano todo.

Material selecionado - Conde, set. 2003, N.G. Jesus et al. 1833 (HUEFS, HUNEBA); Entre Rios, abr. 2004, S. Portugal \& A.M. Miranda 4 (HUEFS); Ilhéus, out. 2000, R.P. Oliveira et al. 674 (HUEFS); Mata de São João, set. 2000, R.P. Oliveira et al. 670 (HUEFS); Salvador, set. 2000, R.P. Oliveira et al. 671 (HUEFS).

Euphorbia bahiensis é similar a E. hyssopifolia, pelo hábito ereto e forma das folhas, porém apresenta dicásios pouco ramificados e sem eixos congestos, enquanto $E$. hyssopifolia apresenta dicásios bastante ramificados e com eixos laterais congestos. Além disso, E. bahiensis ocorre apenas em restingas com solos arenosos, enquanto E. hyssopifolia é uma espécie ruderal, encontrada em diversos tipos de ambientes.

6. Euphorbia chamaeclada Ule, Bot. Jahrb. Syst. 42: 224. 1908.

Figuras $1 \mathrm{~N}-\mathrm{X}$ e 3.

Ervas prostradas; ramos esverdeados a vináceos, glabros. Folhas opostas, membranáceas; limbo elíptico, 5,5-7,5 × 4,5-5,5 mm, ápice arredondado a mucronado, base assimétrica, margens inteiras, planas, faces abaxial e adaxial glabras; pecíolo 0,5-1 $\mathrm{mm}$ compr.; estípulas triangulares, 0,5-1 mm compr., fimbriadas, glabras. Ciátios zigomorfos, solitários ou em dicásios, axilares; pedúnculos 1-2 mm compr.; invólucro campanulado, 2-2,5 × 2-2,5 $\mathrm{mm}$, glabros externamente, vilosos internamente próximo aos nectários; lobos triangulares, ciliados, amarelo- 
esverdeados; nectários 4, sésseis, transversalmente elípticos, amarelo-esverdeados; apêndices 4, desiguais, 2 menores obovados, 2 maiores pandurados, glabros, brancos; bractéolas lineares, pubescentes no ápice. Flores estaminadas ca. 20 por ciátio, 2-3 mm compr.; pedicelo $1,5-2 \mathrm{~mm}$ compr. Flores pistiladas $2-3 \mathrm{~mm}$ compr.; ovário globoso, ca. 1,5 × 1,8 mm, glabro; estiletes unidos na base, ramos 2-partidos, patentes, glabros; estigmas capitados; pedicelo 1,5-2 $\mathrm{mm}$ compr. Frutos globosos, ca. 2,5 × 2,5 mm, glabro, amarelo-esverdeados; pedicelo ca. $3 \mathrm{~mm}$ compr.; sementes castanhas, ovais ca. $1,7 \times 1 \mathrm{~mm}$, com $6-8$ costelas transversais.

Endêmica da Bahia. B6 e D5: caatinga arenosa. Encontrada com flores em janeiro e fevereiro e com frutos em julho.

Material selecionado - Casa Nova, jul. 2003, L.P. Queiroz et al. 7888 (HUEFS); Gentio do Ouro, fev. 1977, R.M. Harley et al. 18980 (CEPEC, IPA); Xique-Xique, jan. 1997, M.M. Arbo et al. 7480 (CEPEC).

Euphorbia chamaeclada é semelhante a $E$. prostrata, porém é glabra e apresenta nectários sésseis, transversalmente elípticos, apêndices dos ciátios desiguais e cerca de 20 flores estaminadas por ciátio, enquanto E. prostrata possui indumento puberulento, nectários estipitados, suborbiculares, apêndices iguais e apenas cinco flores estaminadas por ciátio. Ule (1908) comparou E chamaeclada a E. adenoptera, porém, segundo Müller (1874), E. adenoptera é uma espécie pubérula, com invólucro dos ciátios cilíndricos, nectários côncavos e 5 a 10 flores estaminadas por ciátio, sendo portanto bastante diferente de $E$. chamaeclada.

7. Euphorbia comosa Vell., Fl. Flumin. 5: 202; pl. 15. 1825 .

Figuras 4A-I e 5.

Ervas eretas, ca. $0,4 \mathrm{~m}$ alt.; ramos suculentos, eretos, cilíndricos, verdes, glabros a pubescentes. Folhas alternas, passando a verticiladas no ápice dos ramos, membranáceas; limbo oval, 18-83 × 33-50 $\mathrm{mm}$, ápice apiculado a arredondado, base atenuada, margens inteiras; face abaxial e adaxial glabras; pecíolo 8-20 mm compr., estípulas falcadas, ca. $1 \mathrm{~mm}$ compr., agudas, glabras. Ciátios actinomorfos, monoclinos, em monocásios terminais; pedúnculo 1-2 mm compr.; brácteas orbiculares, 9-10 × 7-8 mm, conduplicadas, ápice acuminado, margens inteiras; invólucro turbinado, 1-1,5 × 1,5-2 mm, glabro; lobos truncados, margens inteiras, amarelo-esverdeados; nectários 4, elípticos, verde-amarelados; apêndices 4, elípticos, crenulados, amarelo-esbranquiçados; bractéolas linear-lanceoladas, glabras. Flores estaminadas 7 ou 8 por ciátio, 2,5-3 mm compr.; pedicelo 1-1,5 mm compr. Flores pistiladas ca. $3 \mathrm{~mm}$ compr.; ovário cilíndrico, ca. $1 \times 0,5 \mathrm{~mm}$, glabro; estiletes unidos na base, inteiros, eretos; estigmas capitados. Frutos cilíndricos, 3-4 × 2,5-3 mm, glabros, amarelo-esverdeados; pedicelo ca. $3 \mathrm{~mm}$ compr.; sementes púrpura, alongadas, ca. 3,7 × 1,5 $\mathrm{mm}$, sem ornamentação, com carúncula.

Espécie ruderal que ocorre na Bolívia, Brasil, Colômbia e Venezuela; no Brasil, é encontrada em Alagoas, Amazonas, Bahia, Espírito Santo, Goiás, Maranhão, Mato Grosso, Mato Grosso do Sul, Minas Gerais, Paraíba, Pernambuco, Piauí, Rio de Janeiro, Rio Grande do Norte, São Paulo, Sergipe e Tocantins. C7, C8, D2, D7, D8, E7, E8, E9, E/F3 F4, F6, F7, F8, G5, G6, G7, H8 e J8: cerrado, caatinga, mata estacional, mata atlântica e restinga. Encontrada com flore ou frutos durante o ano todo.

Material selecionado - Aracatu, jan. 1974, R.M. Harley et al. 15023 (IPA); Bom Jesus da Lapa, abr. 1980, R.M. Harley 21602 (CEPEC, SPF); Bom Jesus da Serra, jan. 2009, A.A. Conceição et al. 3109 (HUEFS); Brumado, abr. 1983, A.M. Carvalho et al. 1689 (CEPEC); Cachoeira, jun. 1980, Grupo Pedra do Cavalo 151 (CEPEC, HRB, HUEFS); Candeal, jan. 1997, M.M. Arbo et al. 7248 (CEPEC); Caetité, fev. 1997, L.M. Guedes et al. PCD 5273 (ALCB, CEPEC, HRB, HUEFS); Contendas do Sincorá, fev. 2000, M.M. Silva et al. 341 (HUEFS); Entre Rios, maio 2007, A.V. Popovikin 15 (HUEFS); Feira de Santana, jul. 1987, L.P. Queiroz et al. 1748 (HUEFS); Formosa do Rio Preto, mar. 2000, E.B. Miranda-Silva et al. 315 (HUEFS); Ipirá, maio 2000, J.M. Santos s.n. (HUEFS 45308); Itaberaba, dez. 1996, R.M. Harley 28451 (HUEFS); Iaçu, mar. 1985, L.R. Noblick 3684 (CEPEC, HUEFS); Itaju, jan. 1971, J.M. Santos 1324 (CEPEC); Jacobina, jul. 1996, R.M. Harley et al. PCD 3404 (ALCB, CEPEC, HRB, HUEFS); Jequié, fev. 1983, A.M. Carvalho \& P. Plowman 1595 (CEPEC); Jussari, set. 1999, W. Thomas et al. 11949 (CEPEC); Mairi, set. 1980, R.P. Orlandi 294 (HRB); Manoel Vitorino, maio 2002, M.M Silva-Castro et al. 548 (HUEFS); Milagres, mar. 1997, F. França 2168 (CEPEC, HUEFS); Mirangaba, set. 1981, L.M.C. Gonçalves 204 (HRB); Morro do Chapéu, out. 2007, A.C. Pereira 79 (HUEFS); Nilo Peçanha, abr. 1980, T.S. Santos et al. 3607 (CEPEC); Retirolândia, nov. 1999, R.P. Oliveira 272 (HUEFS); Riachão do Jacuípe, jul. 1985, L.R. Noblick 4089 (HUEFS); Rio de Contas, fev. 1997, S. Atkins et al. PCD 5086 (ALCB, CEPEC, HRB, HUEFS); Ruy Barbosa, fev. 1991, N. Taylor et al. 1578, 1563 (CEPEC); Santana, fev. 2000, L.P. Queiroz et al. 6009 (HUEFS); Santo Estevão, maio 1987, L.P. Queiroz 1524 (HUEFS); Senhor do Bonfim, fev. 1974, R.M. Harley 16379 (CEPEC); Serra Preta, jul. 1985, L.R. Noblick \& M.J. Lemos 4231 (HUEFS); Teixeira de Freitas, maio 1997, T.S. Santos 1626 (CEPEC).

Euphorbia comosa é semelhante vegetativamente a E. heterodoxa, porém apresenta limbo foliar oval, estípulas falcadas, nectários elípticos, apêndices dos ciátios elípticos e 7 ou 8 flores estaminadas por ciátio, enquanto $E$. heterodoxa possui limbo oval-lanceolado a oboval, estípulas glanduliformes, nectários obdeltoides, ciátios sem apêndices e 20 flores estaminadas por ciátio.

8. Euphorbia crossadenia Pax \& K.Hoffm., Repert. Spec. Nov. Regni. Veg. 19: 174. 1923.

Figuras 4J-R e 5.

Subarbustos a ervas eretos, ca. 0,4 m alt.; ramos não suculentos, eretos, verdes a castanhos, pubérulos quando jovens, glabrescentes. Folhas sésseis, 


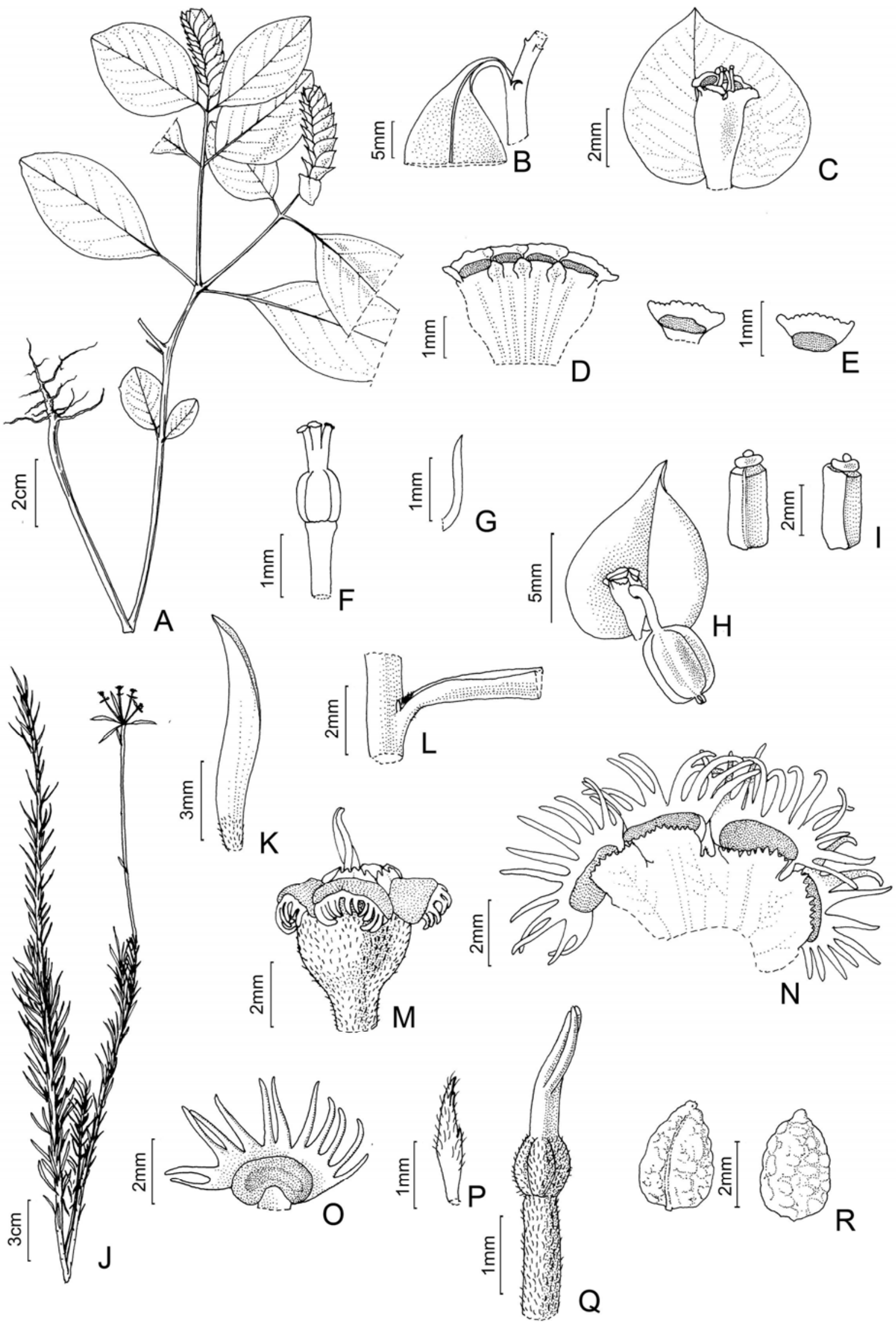

Figura 4. A-I. Euphorbia comosa: A- hábito; B- estípula; C- ciátio e bráctea; D- ciátio, corte longitudinal; E- apêndices e nectários, vista frontal; F- flor pistilada; G- bractéola; H- ciátio com fruto e bráctea; I- sementes, vistas frontal (à esquerda) e lateral (à direita) (Guedes PCD 5273). J-R. E. crossadenia: J- hábito; K- folha, face adaxial; L- estípula; M- ciátio; N- ciátio, corte longitudinal; O- apêndice e nectário, vista frontal; P- bractéola; Q- flor pistilada; R- sementes, vistas dorsal (à direita) e frontal (à esquerda) (Ganev 2028). 
espiraladas, passando a verticiladas no ápice dos ramos, coriáceas; limbo linear, convoluto, 10-16 $\times$ 0,5-1,5 mm, ápice acuminado a agudo, base atenuada, margens inteiras, face abaxial e adaxial glabras; estípulas inconspícuas, glandulares. Ciátios actinomorfos, monoclinos, em umbelas compostas, terminais; pedúnculo ca. 1,5 mm compr.; brácteas lanceoladas, ca. $7 \times 1 \mathrm{~mm}$, aguda, margens inteiras; invólucro campanulado, ca. 2,5 × 3,5 mm, puberulento; lobos obovados, fimbriados, amarelo-esverdeados; nectários 4, elípticos, vináceos a castanhos; apêndices 4, palmados, 11- ou 12-partidos, lacínios lanceolados, avermelhados; bractéolas lanceoladas, fimbriadas, pilosas. Flores estaminadas ca. 30 por ciátio, 2-3 mm compr.; pedicelo 2-2,5 $\mathrm{mm}$ compr. Flores pistiladas 3-4 mm compr.; ovário subgloboso, ca. $1 \times 1 \mathrm{~mm}$, pubérulo; estiletes unidos na base, inteiros, eretos; estigmas obtusos; pedicelo ca. $1 \mathrm{~mm}$ compr. Frutos subglobosos, 3,5-5,5 × 3-5 mm, pubérulos, castanhoesverdeados; pedicelo ca. $4 \mathrm{~mm}$ compr.; sementes castanhas, ovais, 3,5 $\times 2 \mathrm{~mm}$, verrucosas, com carúncula.

Endêmica da Bahia. F6: campo rupestre, sobre solo arenoso. Encontrada com flores ou frutos de julho a outubro.

Material selecionado - Rio de Contas, abr. 2003, A.M. Giulietti 2417 (HUEFS).

Euphorbia crossadenia é semelhante a E. sarcodes, porém possui folhas lineares (vs. espatuladas em $E$. sarcodes) e invólucro do ciátio puberulento (vs. glabro), com ca. 30 flores estaminadas (vs. ca. 20).

9. Euphorbia dioeca Kunth, Nov. Gen. Sp. (quarto ed.) 2: 53.1817.

\section{Figura 5.}

Ervas prostradas; ramos vináceos a esverdeados, pubescentes. Folhas opostas, membranáceas, actinódromas; limbo elíptico, 5-10 × 2,5-5 mm, ápice obtuso a arredondado, base assimétrica, margens serreadas a inconspicuamente serreadas, faces abaxial e adaxial esparsamente pubescentes; pecíolo ca. $1 \mathrm{~mm}$ compr.; estípulas lanceoladas, 0,8-1 $\mathrm{mm}$ compr., inteiras, glabras. Ciátios zigomorfos, solitários a geminados, axilares; pedúnculo 1-2 mm compr.; invólucro turbinado, $1-1,5 \times 0,5-0,7 \mathrm{~mm}$, pubescente; lobos triangulares, margens inteiras, ciliadas, esverdeados; nectários 4, elipsoidais, verdes a rosados; apêndices 4, desiguais, reniformes, glabros, brancos a levemente rosados; bractéolas ausentes. Flores estaminadas 4 ou 5 por ciátio, ca. 1,5 mm compr.; anteras púrpura; pedicelo ca. 0,7 $\mathrm{mm}$ compr. Flores pistiladas $1-1,5 \mathrm{~mm}$ compr.; ovário globoso, $0,5-0,8 \times$ $0,5-0,8 \mathrm{~mm}$, pubescente; estiletes unidos na base, ramos 2-partidos, eretos, glabros; estigmas indiferenciados; pedicelo 0,6-1 mm compr. Frutos subglobosos, 1-1,5 $\times$ 1,2-1,4 mm, pubescentes, verdes a avermelhados; pedicelo 1-1,5 $\mathrm{mm}$ compr.; pêndulo sem romper o invólucro; sementes castanhas, ovais, 0,8-1 $\times 0,4-0,5$ $\mathrm{mm}$, com 4-8 costelas transversais estreitas.

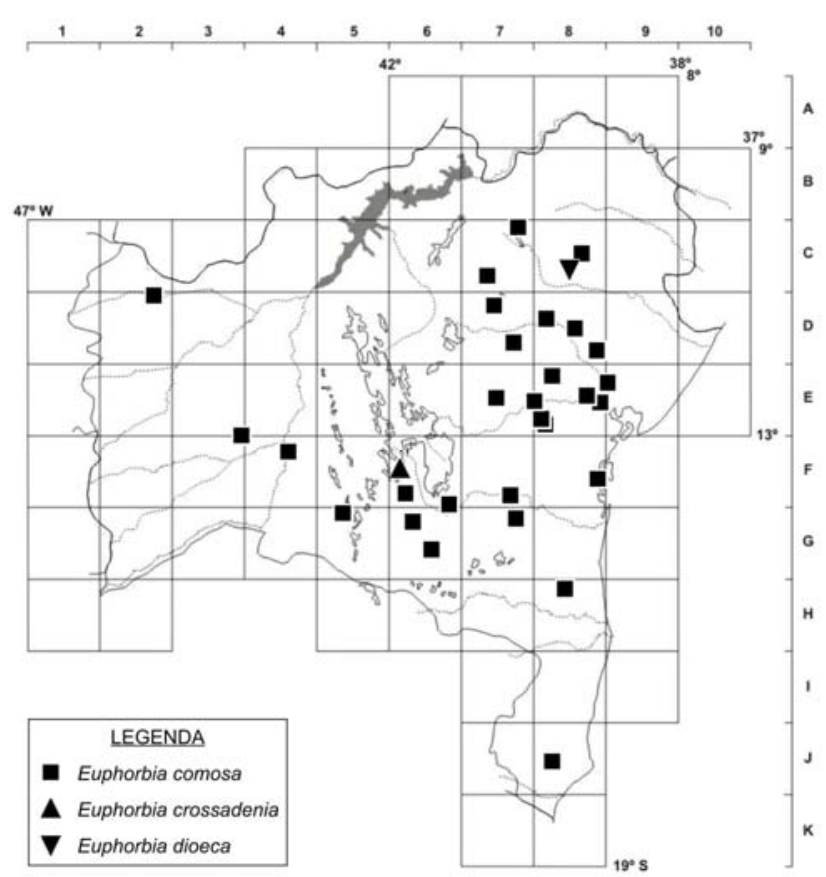

Figura 5. Mapa de distribuição geográfica de Euphorbia comosa, E. crossadenia e E. dioeca no estado da Bahia.

Amplamente distribuída por toda América Tropical; no Brasil, ocorre na Bahia, Espirito Santo, Goiás, Santa Catarina e São Paulo. C8: áreas antropizadas. Encontrada com flores e/ou frutos em fevereiro, março e junho.

Material selecionado - Cansanção, fev.1994, R.M. Harley 16487 (CEPEC, MO, NY, US).

Euphorbia dioeca é semelhante a E. adenoptera e E. thymifolia, diferindo destas principalmente pela mancha escura na face adaxial das folhas e a cor alva dos apêndices das glândulas do ciátio (veja comentários em E. adenoptera).

10. Euphorbia flaviana Carn.-Torres \& Cordeiro, Syst. Bot. 37(3): 688. 2012.

Figura 6.

Subarbustos eretos, 0,80-1,5 m alt., cactifomes; cladódios verticilados, suculentos, eretos, cilíndricos, verdes a amarronzados, glabros, afilos; estípulas insconspícuas. Folhas rudimentares, lanceoladas, 2$2,5 \times 1-1,5 \mathrm{~mm}$, decíduas. Ciátios actinomorfos, monoclinos, solitários a geminados, terminais, sésseis a subsésseis; brácteas, lanceoladas, 1-1,5 × 0,8-1 mm, ápice agudo, margens frimbriadas; invólucro turbinado, 1,5-2,2 × 2,0-2,5 mm, glabro; lobos triangulares, amarelo-esverdeados, margens ciliadas; nectários 5, elípticos, 0,8-1 mm compr., amarelo-esverdeados, glabros; apêndices ausentes; bractéolas lanceoladas, ciliadas. Flores estaminadas ca. 20 por ciátio, $0,5-0,8$ $\mathrm{mm}$ compr.; anteras amarelas; pedicelo 1,5-2 $\mathrm{mm}$ compr. Flores pistiladas 2-2,5 $\mathrm{mm}$ compr.; ovário globoso, 1-1,5 × 1-1,5 mm, glabro; estiletes unidos na base, recurvados, 0,5-1 $\mathrm{mm}$ compr.; estigmas enrolados; pedicelo ca. 1,5 $\mathrm{mm}$ compr. Frutos globosos, ca. $3 \times 4,5 \mathrm{~mm}$, glabros, avermelhados; 
pedicelo 3-4 mm compr.; sementes castanho-escuras, ovoides, ca. 2,6 $62 \mathrm{~mm}$, sem carúncula.

Endêmica da Bahia. C7, D7, E8 e F6: campo rupestre e inselbergs na caatinga. Encontrada com flores ou frutos de dezembro a julho.

Material selecionado - Barra da Estiva, fev. 1997, M.L. Guedes et al. PCD 5739 (ALCB, HUEFS); Itatim, jul. 2001, D.S. Carneiro-Torres et al. 1005 (HUEFS); Jacobina, mar. 1996, M.L. Guedes et al. PCD 2723 (ALCB, HUEFS, SP); Milagres, mar. 1997, F. França et al. 2151 (HUEFS, SP); Pindobaçu, dez. 2013, A.M. Miranda et al. 4265 (HUEFS); Santa Terezinha, set. 1997, E.B. Miranda et al. 4 (HUEFS).

Euphorbia flaviana é similar a E. gymnoclada, porém possui cladódios verticilados, ciátios sem apêndices ou apêndices inteiros, com menos de $2 \mathrm{~mm}$ de comprimento, e estigmas enrolados, enquanto em $E$. gymnoclada, os ramos não são verticilados, os apêndices dos ciátios são 3-5-partidos e os estigmas eretos.

11. Euphorbia goyazensis Boiss., Cent. Euphorb.: 28. 1860.

Figuras 6 e $7 \mathrm{~A}-\mathrm{I}$.

Ervas eretas, até $0,5 \mathrm{~m}$ alt.; ramos não suculentos, eretos, cilíndricos, verdes, glabros. Folhas sésseis a subsésseis, alternas, passando a verticiladas no ápice dos ramos, coriáceas; limbo lanceolado a linear-lanceolado, 13-32 × 1-2 mm, ápice acuminado, base cuneada, margens inteiras, faces abaxial e adaxial glabras; estípulas glanduliformes, glabras. Ciátios actinomorfos, monoclinos, em umbelas, terminais; pedúnculo ca. 10 mm compr.; brácteas orbiculares a arredondadas, 6-8 $\times$ 3,5-4 mm, ápice acuminado, margens inteiras; invólucro turbinado, 2,5-4 × 2,5-3,5 mm, glabrescente, amareloesverdeado; lobos obovados, margens inteiras, ciliadas; nectários 4 ou 5, elípticos, verdes passando a vermelhos; apêndices palmados, 5-7-partidos, róseo-esbranquiçados passando a vermelhos; bractéolas lanceoladas, inteiras, glabras. Flores estaminadas $15-20$ por ciátio, 3,5-6 $\mathrm{mm}$ compr.; pedicelo 1,5-3,5 $\mathrm{mm}$ compr. Flores pistiladas 3-4 mm compr.; ovário globoso, 1-2 × 1-1,5 mm, glabro; estiletes unidos até a metade, inteiros, patentes; estigmas agudos; pedicelo 1,5-2 mm compr. Frutos globosos, ca. $4 \times 4,5 \mathrm{~mm}$, glabros, amareloesverdeados; pedicelo 3,5-6,5 mm compr.; sementes castanho-escuras, ovais, ca. $2,7 \times 2 \mathrm{~mm}$, verrucosas, com carúncula inconspícua.

No Brasil, ocorre de Pernambuco a Minas Gerais. C6, D2 e D6: cerrado e campo rupestre sobre solo arenoso. Encontrada com flores ou frutos de janeiro a agosto.

Material selecionado - Formosa do Rio Preto, abr. 2000, R.M. Harley et al. 53891 (HUEFS); Morro do Chapéu, jun. 2003, F. França et al. 4691 (HUEFS); Umburanas, abr. 1999, L.P. Queiroz et al. 5196 (HUEFS).

Euphorbia goyazensis é semelhante a E. sessilifolia, mas possui ramos glabros (vs. pubérulos em $E$. sessilifolia), ciátios em umbelas (vs. solitários) e apêndices 5-7-partidos (vs 8- ou 9-partidos).
12. Euphorbia gymnoclada Boiss., Cent. Euphorb.: 20. 1860.

Figuras 6 e 7J-U.

Ervas, ca. 0,3 m alt., cactiformes; cladódios não verticilados, suculentos, eretos a procumbentes, inteiros, cilíndricos, verdes, glabros, áfilos; estípulas obovadas, 1-1,5 mm compr., agudas, glabras. Ciátios actinomorfos, monoclinos, solitários, terminais; pedúnculo ca. $1 \mathrm{~mm}$ compr.; brácteas obovadas a orbiculares, 1,5-2,8 × 1,4-2,3 mm, ápice emarginado a apiculado, margens inteiras; involúcro turbinado, 2-3 $\times$ 2,5-3 mm compr., glabrescente; lobos primários obovados, fimbriados, glabros, amarelo-esverdeados; nectários 5, elípticos a triangulares, brancos; apêndices 5, petaloides, 3-5-partidos, lacínios ovais, imbricados, brancos; bractéolas obtriangular, fimbriadas, glabras. Flores estaminadas ca. 20 por ciátio, 1,5-3 $\mathrm{mm}$ compr.; pedicelo 1,5-2 mm compr. Flores pistiladas 1-1,5 mm compr.; ovário globoso, ca. 1,5 × 1,8 mm, glabro; estiletes unidos até a metade, inteiros, eretos; estigmas obtusos; pedicelo 1-2 mm compr. Frutos globosos, 3-4 × 4,3-5,6 mm, glabros, verdes com manchas vináceas; pedicelo ca. 4,5 mm compr.; sementes castanhas, ovais, 3-3,5 × 2-2,5 mm, verrucosas, com carúncula.

Endêmica das restingas da Bahia. E9: restinga, nas dunas da Lagoa do Abaeté sobre solos arenosos. Encontrada com flores ou frutos o ano todo.

Material selecionado - Salvador, abr. 2000, I. Cordeiro et al. 2251 (HUEFS, SP, SPF).

Euphorbia gymnoclada possui cladódios de ramificação dicotômica, caules cilíndricos, áfilos, apêndices 3-5-partidos, com lacínios ovais, distinguindo-se assim de todas as espécies de Euphorbia cactiformes da Bahia.

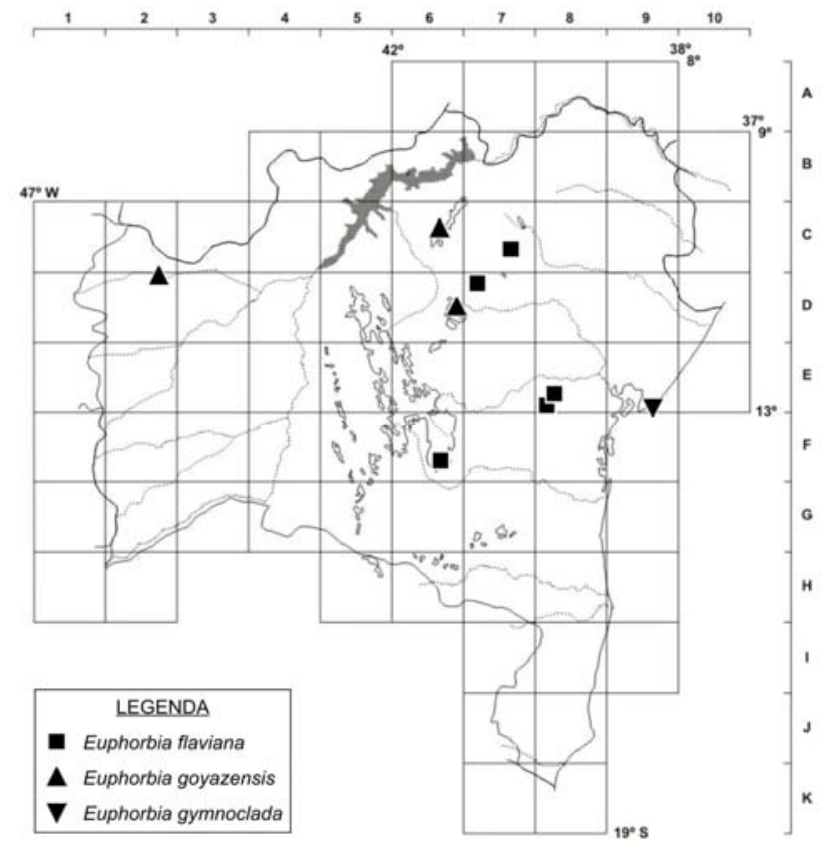

Figura 6. Mapa de distribuição geográfica de Euphorbia flaviana, E. goyazensis e E. gymnoclada no estado da Bahia. 


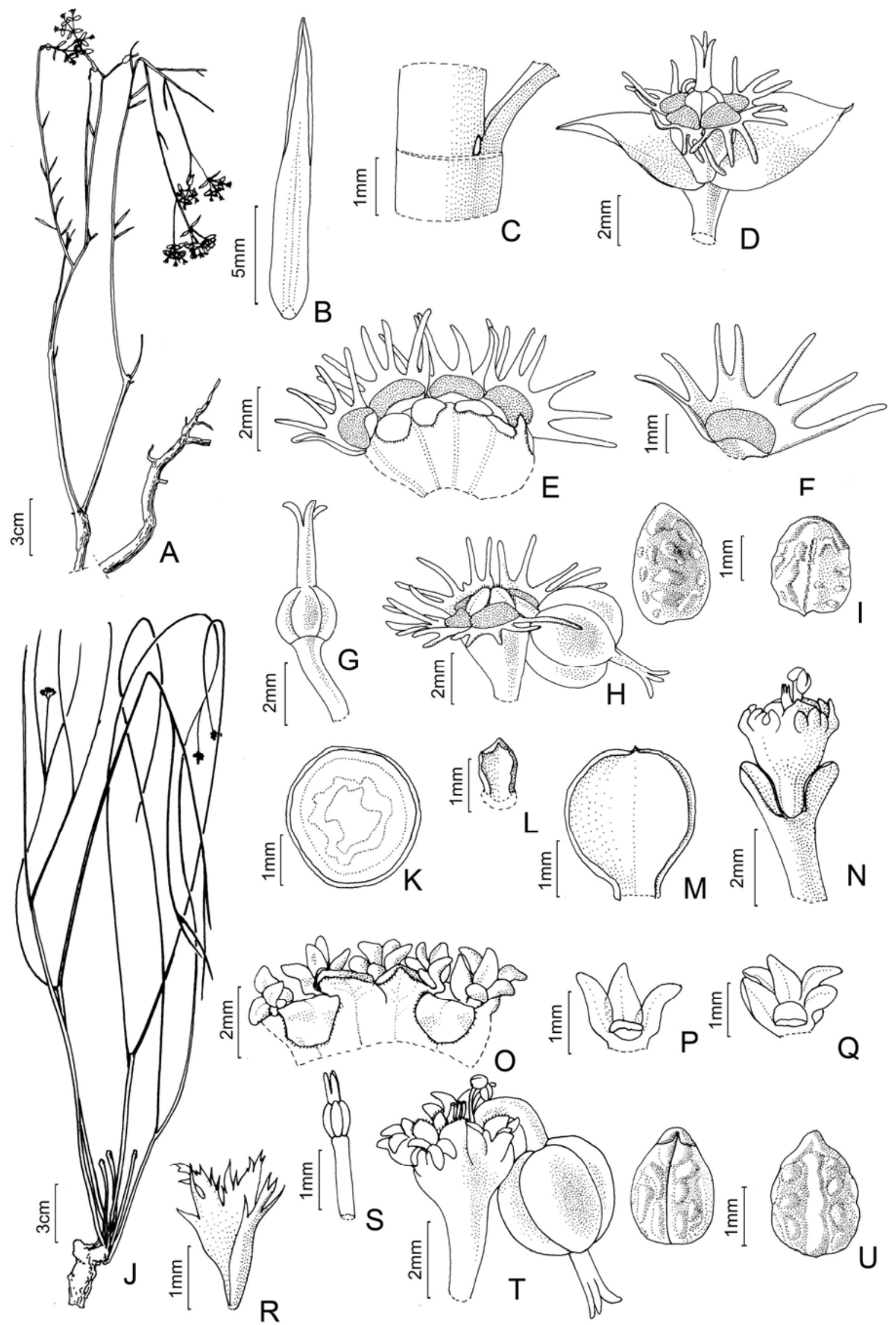

Figura 7. A-I. Euphorbia goyazensis: A- hábito; B- folha; face adaxial C- estípula; D- ciátio e brácteas; E- ciátio, corte longitudinal; F- apêndice e nectário, vista frontal; G- flor pistilada; H- ciátio com fruto; I- sementes, vistas lateral (à esquerda) e frontal (à direita) (Carneiro-Torres 136). J-U. E. gymnoclada: J- hábito; K- cladódio, corte transversal; L- estípula face adaxial; M- bráctea, face adaxial; N- ciátio com brácteas; O- ciátio, corte longitudinal; P- nectário e apêndice 3-partido, vista frontal; Q- nectário e apêndice 5-partido, vista frontal; R- bractéola; S- flor pistilada; T- ciátio com fruto; U- sementes, vistas frontal (à esquerda) e dorsal (à direita) (Harley 15684). 
13. Euphorbia heterodoxa Müll. Arg., Fl. Bras. 11(2): 701.1874.

Figuras 8A-J e 9.

Ervas eretas, ca. 0,2 $\mathrm{m}$ alt., pouco ramificadas; ramos suculentos, eretos, cilíndricos, verdes, glabros. Folhas alternas, passando a verticiladas no ápice dos ramos, caducas, membranáceas; limbo oval-lanceolado a oboval, 15-16 × 5-6 mm, ápice obtuso a acuminado, base subcordada a atenuada, margens inteiras, faces abaxial e adaxial glabras; pecíolo 5-10 $\mathrm{mm}$ compr.; estípulas glanduliformes, glabras. Ciátios actinomorfos, monoclinos, dispostos em monocásios terminais; pedúnculo 1-1,5 $\mathrm{mm}$ compr.; brácteas orbiculares, ca. $10 \times 9 \mathrm{~mm}$, conduplicadas, ápice agudo, margens inteiras; invólucro turbinado, 3-4 × 2$3 \mathrm{~mm}$, glabro; lobos truncados, fimbriados, amareloesverdeados; nectários 4, obdeltoides, amareloesverdeados; apêndices ausentes; bractéolas lineares, inteiras, glabras. Flores estaminadas ca. 20 por ciátio, 2-2,5 mm compr.; pedicelo 1-1,5 mm compr. Flores pistiladas 3-3,5 mm compr.; ovário cilíndrico, ca. $2 \times$ $1 \mathrm{~mm}$, glabro; estiletes unidos na base, ramos curtamente 2-partidos, eretos; estigmas capitados; pedicelo 1-1,5 mm compr. Frutos alongados, ca. 5,5 $\times$ $4 \mathrm{~mm}$, glabros, amarelo-esverdeados; pedicelo ca. 4,5 mm compr.; sementes castanhas, alongadas, 3,4 × 2,3 $\mathrm{mm}$, sem ornamentação, com carúncula.

Ocorre em Alagoas, Bahia, Paraíba, Pernambuco e Rio Grande do Norte. B9, C8, D6, D7, D8/9, E8, F4 e F7: caatinga e mata estacional, sobre solo argiloarenoso com afloramentos rochosos. Encontrada com flores ou frutos o ano todo.

Material selecionado - Bom Jesus da Lapa, fev. 2000, L.P. Queiroz et al. 5853 (HUEFS); Casa Nova, fev. 2008, C. Correia et al. 425 (HUEFS); Itaberaba, jul. 2006, L.P. Queiroz et al. 12207 (HUEFS); Itatim, out. 1996, F. França et al. 1940 (HUEFS); Jacobina, jun. 1999, F. França et al. 3145 (HUEFS); Jequié, maio 2002 D.S. Carneiro-Torres 221 (HUEFS); Maracás, abr. 2002, K.R.B. Leite et al. 263 (HUEFS); Milagres, mar. 1997, F. França et al. 2182 (HUEFS); Monte Santo, mar. 1974, R.M. Harley et al. 16419 (CEPEC, IPA); Morro do Chapéu, abr. 2000, I. Cordeiro et al. 2234 (HUEFS, SP, SPF); Paulo Afonso, set. 2008, A.A. Conceição et al. 3034 (HUEFS); Santa Brígida, jun. 1982, L.P. Queiroz et al. 387 (HUEFS); Serrinha, ago. 2003, F. França et al. 4814 (HUEFS); Tanquinho, jan. 1997, M.M. Arbo et al. 7229 (HUEFS).

Euphorbia heterodoxa é frequentemente identificada como E. comosa, devido à semelhança entre a forma do limbo e o padrão das inflorescências das duas espécies (para uma comparação entre essas espécies, veja o comentário de E. comosa).

14. Euphorbia heterophylla L., Sp. P1. 1: 453. 1753. Figuras $8 \mathrm{~K}-\mathrm{S}$ e 9.

Ervas eretas, ca. $0,5 \mathrm{~m}$ alt.; ramos um pouco suculentos, eretos, cilíndricos, verdes, esparsamente pubescentes, passando a glabrescentes. Folhas alternas, passando a opostas no ápice dos ramos, membranáceas; limbo oval a oboval, $60-70 \times 29-33 \mathrm{~mm}$, ápice obtuso, agudo a acuminado, base cuneada, margens inteiras, ciliadas, face abaxial pubescente, a adaxial esparsamente pilosa a glabra; pecíolo 4,5-14 mm compr.; estípulas glanduliformes, glabras. Ciátios zigomorfos, monoclinos, em glomérulos; pedúnculo 1,5-3,5 mm compr.; brácteas obovadas, 28-66 × 6-27 $\mathrm{mm}$, ápice agudo, base esbranquiçada; invólucro campanulado, 2,5-3,5 × 1,5-2 mm, glabro; lobos triangulares, fimbriados, amarelo-esverdeados; nectário 1, estipitado, arredondado, amarelo-esverdeado; apêndices ausentes; bractéolas oval-lanceoladas, pubescentes. Flores estaminadas ca. 20 por ciátio, ca. 3,5 mm compr.; pedicelo ca. $3 \mathrm{~mm}$ compr. Flores pistiladas ca. $3 \mathrm{~mm}$ compr.; ovário globoso, $0,5-1 \times$ 0,6-1 mm, glabro; estiletes 2-partidos, eretos; estigmas agudos; pedicelo ca. $2 \mathrm{~mm}$ compr. Frutos globosos, 3,5-4 × 4-6 mm, glabros, esverdeados; pedicelo ca. 3 $\mathrm{mm}$ compr.; sementes purpúreas, ovais a arredondadas, $2-2,5 \times 2-2,2 \mathrm{~mm}$, verrucosas, com carúncula inconspícua.

Ampla distribuição pela América Tropical, estendendo-se até à Argentina (Oliveira \& Sá-Haiad 1988); no Brasil, ocorre no Amapá, Amazonas, Bahia, Distrito Federal, Espírito Santo, Goiás, Maranhão, Mato Grosso, Mato Grosso do Sul, Minas Gerais, Pará, Paraíba, Paraná, Pernambuco, Rio de Janeiro, Rio Grande do Sul, Rondônia, Santa Catarina e São Paulo. A9, C6, C9, D7, E6, E8, E9, F3, F6, G8, H8 e I8: mata atlântica, mata estacional e caatinga, sobre solo argiloso com afloramentos rochosos. Encontrada com flores ou frutos o ano todo.

Material examinada - Cruz das Almas, jul. 1981, H.P. Bautista 502 (HRB); Entre Rios, mar. 2009, A.V. Popovkin 536 (HUEFS); Ilhéus, out. 1997, L.A. Mattos-Silva et al. 3599 (UESC); Jussari, set. 2001, R.P. Oliveira et al. 736 (HUEFS); Lençóis, mar. 1984, L.R. Noblick 3040 (HUEFS); Miguel Calmon, jun. 1985, L.R. Noblick 3928 (HUEFS); Porto Seguro, dez. 1991, M.C. Ferreira 424 (HRB); Ribeira do Pombal, mar. 1984, L.R. Noblick 2936 (HUEF); Rio de Contas, ago. 2000, D.S. Carneiro-Torres 211 (HUEFS); Rodelas, jan. 1987, L.A. Mattos-Silva \& Silva 54 (HRB); Salvador, fev. 1992, J. Costa \& A.S. Conceição 121 (HRB); Santa Terezinha, maio 2011, E. Melo et al. 9568 (HUEFS); São Félix do Coribe, dez. 1999, E. Melo et al. 3230 (HUEFS); Senhor do Bonfim, jul. 2005, V.J. Santos et al. 438 (HUEFS); Umburanas, mar. 1974, R.M. Harley et al. 16887 (IPA); Urandi, ago. 2009, M.L. Guedes et al. 15911 (ALCB, HUEFS); Uruçuca, ago. 2009, S.G. Lima de 186 (HUEFS).

Euphorbia heterophylla é, por muitas vezes, identificada como E. cyathophora Murray, espécie introduzida no Brasil. Entretanto, E. heterophylla possui brácteas (ciatófilos) esbranquiçadas (vs. vermelhas em E. cyathophora) e nectários estipitados (vs. não estipitados).

\section{Euphorbia hirta L., Sp. Pl. 1: 454. 1753.}

Figuras 9 e $10 \mathrm{~A}-\mathrm{K}$.

Ervas geralmente eretas a suberetas ou decumbentes, ca. 0,4 $\mathrm{m}$ alt.; ramos avermelhados, hirsuto-pubescentes. Folhas opostas, membranáceas; 


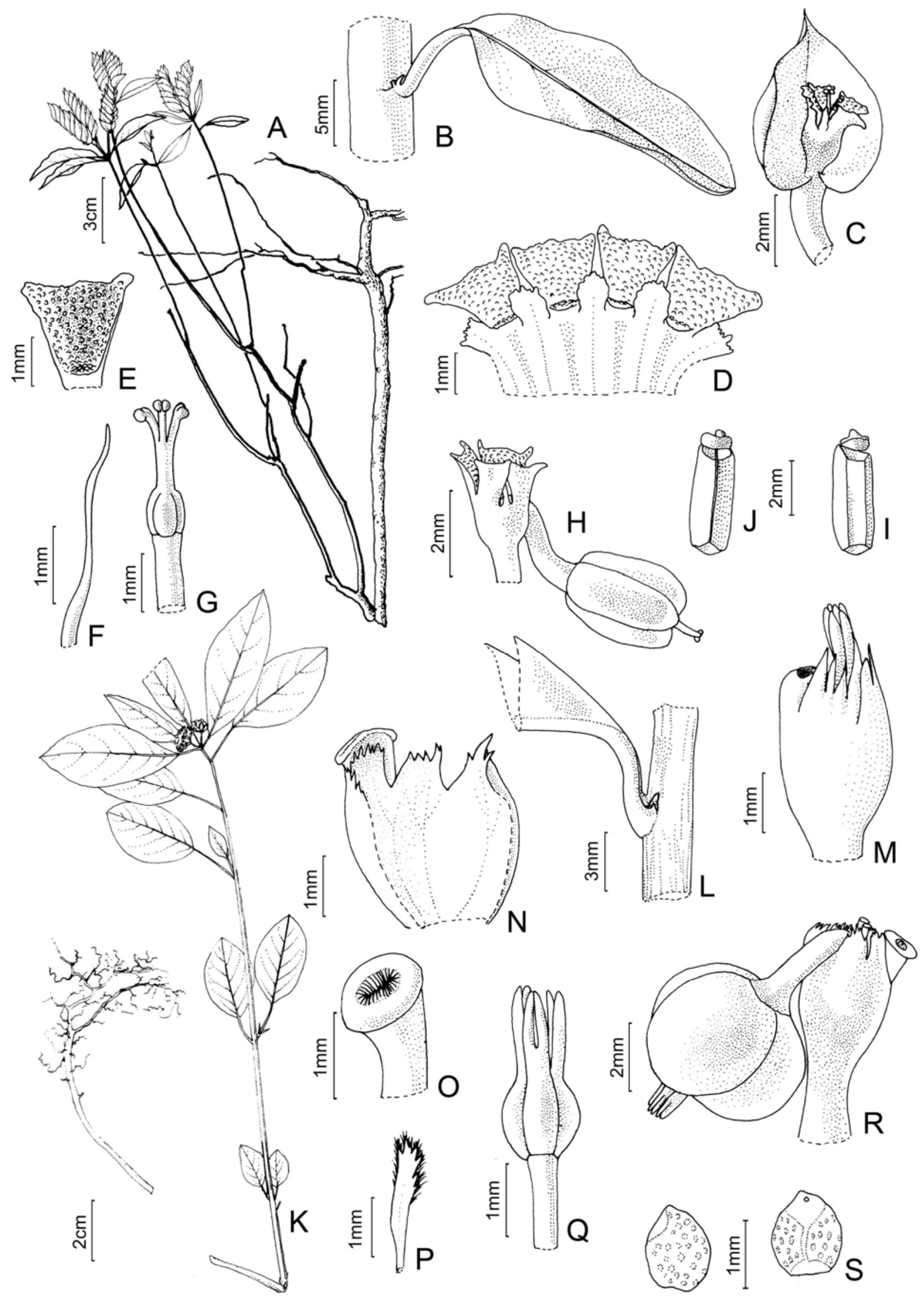

Figura 8. A-J. Euphorbia heterodoxa: A- hábito; B- folha e estípula; C- bráctea e ciátio; D- ciátio, corte longitudinal; E- nectário obdeltoide sem apêndice, vista frontal; F- bractéola; G- flor pistilada; H- ciátio com fruto; I- semente, vista lateral; J- semente, vista frontal (Carneiro-Torres 174). K-S. E. heterophylla: K- hábito; L- estípula; M- ciátio; N- ciátio, corte longitudinal; O- nectário, vista lateral; P- bractéola; Q- flor pistilada; R- ciátio com fruto; S- sementes, vistas dorsal (à esquerda) e frontal (à direita) (Harley 53406). 


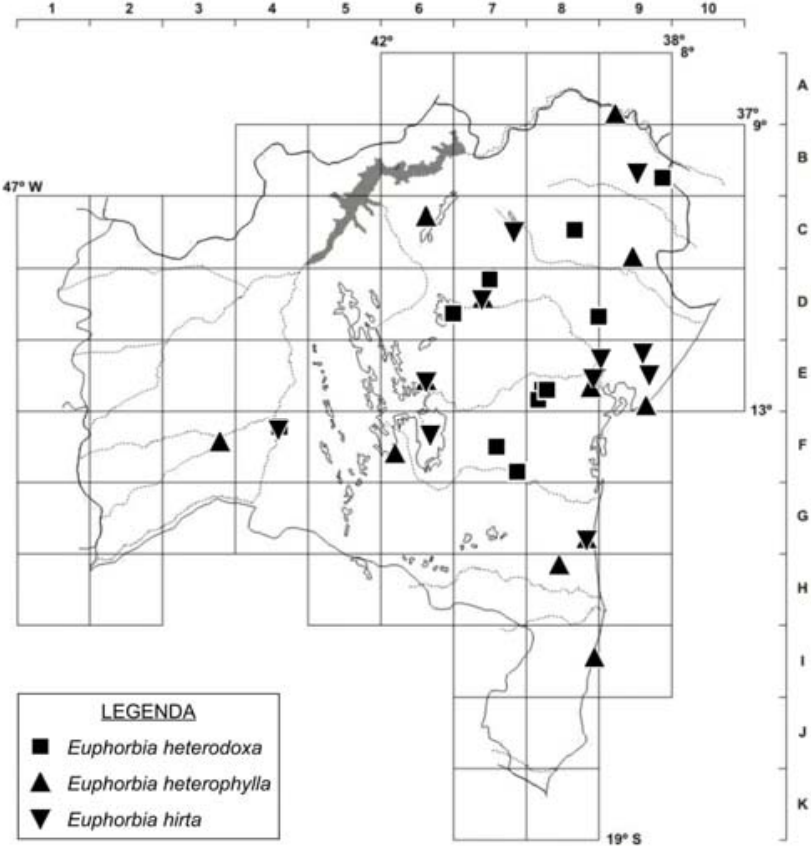

Figura 9. Mapa de distribuição geográfica de Euphorbia heterodoxa, E. heterophylla e E. hirta no estado da Bahia.

limbo largamente trulado a oval-elíptico, $10-37 \times 6-$ $10 \mathrm{~mm}$, ápice obtuso a agudo, base assimétrica, margens irregularmente serrilhadas a serradas, planas, faces abaxial e adaxial hirsuto-pubescentes; pecíolo 1-3 mm compr.; estípulas lineares, $1-1,5 \mathrm{~mm}$ compr., inteiras, glabras. Ciátios actinomorfos, em dicásios glomeruliformes, axilares; pedúnculos 1-2 $\mathrm{mm}$ compr.; invólucros obcônicos, ca. $1 \times 0,8 \mathrm{~mm}$, vilosos externamente; lobos triangulares, margens inteiras, ciliadas, amarelo-esverdeados; nectários 4 , estipitados, orbiculares, amarelo-esverdeados; apêndices 4, desiguais, suborbiculares, glabros, brancos; bractéolas lineares, pubescentes. Flores estaminadas ca. 5 por ciátio, $0,8-1 \mathrm{~mm}$ compr.; pedicelo $0,4-0,6 \mathrm{~mm}$ compr. Flores pistiladas $0,5-1 \mathrm{~mm}$ compr.; ovário globoso, ca. $0,7 \times 0,6 \mathrm{~mm}$, hirsuto-pubescente; estiletes unidos na base, ramos 2-partidos, eretos, glabros; estigmas capitados; pedicelo ca. $0,6 \mathrm{~mm}$ compr. Frutos globosos, 1-1,5 × 1,3-1,8 mm, hirsutopubescentes, amarelo-avermelhados; pedicelo $1-1,3$ mm compr.; sementes castanhas, ovais, $0,6-0,8 \times 0,4-$ $0,6 \mathrm{~mm}$, com 3-5 costelas transversais estreitas, sem carúncula.

Espécie pantropical (Subils 1977); no Brasil, ocorre no Amazonas, Bahia, Ceará, Distrito Federal, Espírito Santo, Goiás, Maranhão, Mato Grosso, Mato Grosso do Sul, Minas Gerais, Paraíba, Pará, Pernambuco, Rio de Janeiro, Rio Grande do Sul, Santa Catarina, São Paulo, Sergipe e Tocantins. B9, C7, D7, E6, E8/9, E9, F4, F6 e G8: ruderal. Encontrada com flores ou frutos o ano todo.

Material selecionado - Abaíra, maio 1992, W. Ganev 387 (HUEFS); Alagoinhas, jan. 2001, N.G. Jesus et al. 518 (HUEFS); Belmonte, mar. 1974, R.M. Harley 17461 (CEPEC); Bom Jesus da Lapa, abr. 2001, J.G. Carvalho-Sobrinho. et al. 516 (HUEFS);
Cachoeira, maio 1980, Grupo Pedra do Cavalo 30 (HUEFS); Camaçari, fev. 1983, L.R. Noblick 2557 (HUEFS); Conceição de Feira, fev. 1998, L.R. Noblick 1939 (HUEFS); Feira de Santana, maio 1983, L.R. Noblick 2610 (HUEFS); Ilhéus, ago. 1995, L.A. Mattos-Silva et al. 3166 (HUEFS, UESC); Lençóis, mar. 1984, L.R. Noblick 2988 (HUEFS); Miguel Calmon, jun. 1985, L.R. Noblick 3850 (HUEFS); Paulo Afonso, nov. 2005. F. França et al. 5332 (HUEFS); Senhor do Bonfim, nov. 2005, J.G. Freitas 75 (HUEFS).

Euphorbia hirta é semelhante a E. hyssopifolia, porém apresenta ciátios em glomérulos (vs. em dicásios, em E. hyssopifolia) e indumento hirsutopubescente (vs. esparsamente viloso).

16. Euphorbia hyssopifolia L., Syst. Nat. (ed. 10) 2: 1048. 1759.

Figuras 10L-U e 11.

Ervas eretas, ca. $0,5 \mathrm{~m}$ alt.; ramos levemente avermelhados; caule esparsamente viloso. Folhas opostas, membranáceas; limbo oblongo a elípticooblongo, 14-20 × 6-11 mm, ápice obtuso a apiculado, base assimétrica, margens esparsamente serrilhadas, planas, faces abaxial e adaxial esparsamente vilosas; pecíolo 1-1,5 mm compr.; estípulas triangulares, 1-1,5 $\mathrm{mm}$ compr., inteiras, pilosas. Ciátios actinomorfos, solitários, em dicásios, axilares ou terminais; pedúnculos $0,5-2 \mathrm{~mm}$ compr.; invólucro obcônico, $1,5-2,5 \times 0,8-1,6 \mathrm{~mm}$, glabros; lobos triangulares, margens inteiras, ciliadas, amarelo-esverdeados; nectários 4, estipitados, pateliformes, amarelos; apêndices 4 , desiguais, orbiculares, glabros, brancos a avermelhados; bractéolas fimbriadas, pilosas. Flores estaminadas ca. 20 por ciátio, $1,5-2 \mathrm{~mm}$ compr.; pedicelo ca. 1,3 mm compr. Flores pistiladas 1-1,5 $\mathrm{mm}$ compr.; ovário subgloboso, ca. 0,6 0 0,5 mm, glabro; estiletes unidos na base, ramos 2-partidos, eretos; estigmas arredondados; pedicelo $0,5-1 \mathrm{~mm}$ compr. Frutos subglobosos, $1-1,5 \times 1-1,4 \mathrm{~mm}$, glabros, amarelo-avermelhados; pedicelo 1-2 $\mathrm{mm}$ compr.; sementes castanhas, ovais, $0,6-0,8 \times 0,4-0,5$ $\mathrm{mm}$, com 3 ou 4 costelas transversais estreitas, sem carúncula.

Amplamente distribuída na região neotropical (Subils 1977); no Brasil, ocorre no Acre, Alagoas, Amapá, Amazonas, Bahia, Ceará, Distrito Federal, Espírito Santo, Goiás, Maranhão, Mato Grosso, Mato Grosso do Sul, Minas Gerais, Pará, Pernambuco, Piauí, Rio de Janeiro, Rio Grande do Norte, Rio Grande do Sul, Rondônia, Santa Catarina, São Paulo, Sergipe e Tocantins. B9, C5, C7, C9, D4, D6, D7, D8, D10, E6, E7, E8, E9, F5, F6, G7, G8, H8 e I8: ruderal. Encontrada com flores ou frutos o ano todo.

Material selecionado - Abaíra, dez. 1991, D.J.N. Hind \& R.F. Queiroz H50011 (HUEFS); Alagoinhas, dez. 1999, N.G. Jesus \& C.S. Lima 384 (HUEFS); Cachoeira, maio 1980, Grupo Pedra do Cavalo 13 (HUEFS); Camaçari, dez. 1982, L.R. Noblick 2466 (HUEFS); Campo Formoso, ago. 1999, E.B. Miranda-Silva 165 (HUEFS); Canavieiras, dez. 2005, S.F. Conceição et al. 429 (HUEFS); Conde, abr. 1996, E.M. Costa-Neto 13 (HUEFS); 


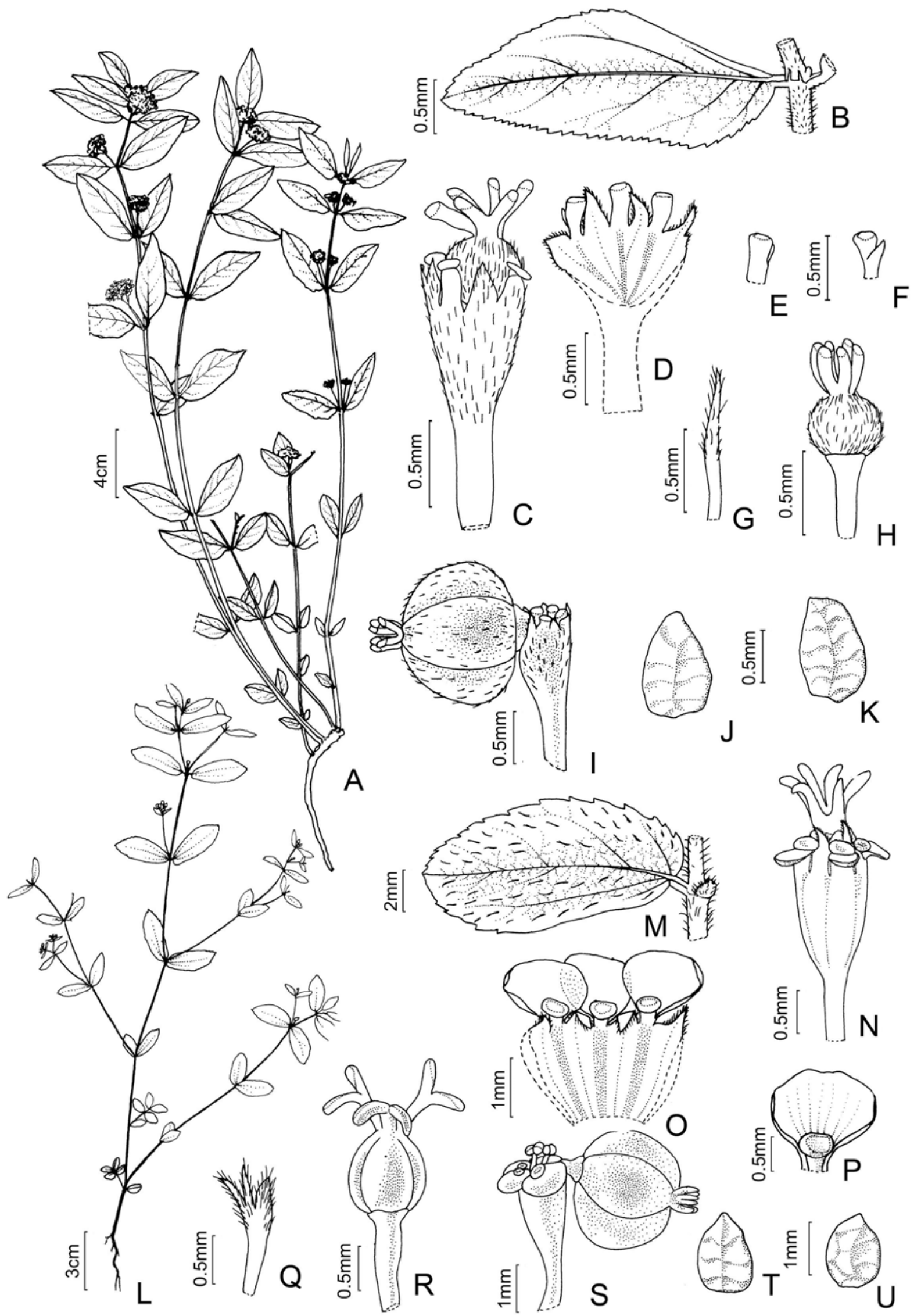

Figura 10. A-K. Euphorbia hirta: A- hábito; B- folha e estípula; C- ciátio; D- ciátio, corte longitudinal; E apêndice e nectário, vista frontal;F- apêndice e nectário, vista lateral; G- bractéola; H- flor pistilada; I- ciátio com fruto; J- semente, vista frontal; K- semente, vista lateral (Guedes PCD 5273). L-U. E. hyssopifolia: L- hábito; M- folha e estípula; N- ciátio; O- ciátio, corte longitudinal mostrando 3 nectários e apêndices; P- apêndice e nectário, vista frontal; Q- bractéola; R- flor pistilada; S- ciátio com fruto; T- semente, vista frontal; U- semente, vista lateral (Noblick 3028). 
Contendas do Sincorá, fev. 2000, M.M. Silva et al. 317 (HUEFS); Entre Rios, mar. 2009, A.V. Popovikin 537 (HUEFS); Esplanada, fev. 2002, J.R. Pirani et al. 4957 (HUEFS, SPF); Feira de Santana, jun. 1982, M.J.S. Lemos 10 (HRB, HUEFS); Glória, abr. 2006, M. Colaço et al. 104 (HUEFS); Ilhéus, abr. 1978, S.A. Mori \& J.A. Kallunki 9855 (CEPEC); Ipecaetá, ago. 1985, L.R. Noblick 4327 (HUEFS); Itaberaba, nov. 1999, M.M. Silva et al. 236 (HUEFS); Itabuna, jul. 1980, L. Coradin et al. 2953 (CEN); Itatim, jun. 1996, E. Melo et al. 1617 (HUEFS); Jacobina jun. 2001, T.S. Nunes et al. 332 (HUEFS); Lençóis, mar. 1984, L.R. Noblick 3028 (HUEFS); Maracás, nov. 2000, M.M. Silva et al. 295 (HUEFS); Maraú, dez. 1999, D.S. Carneiro-Torres 185 (HUEFS); Milagres, fev. 2000, M.M. Silva et al. 360 (HUEFS); Morpará, dez. 2007, A.A. Conceição et al. 2680 (HUEFS); Morro do Chapéu, maio 1980, R.M. Harley 22872 (CEPEC, SP); Pilão Arcado, mar. 2006, E.B. Miranda et al. 961 (HUEFS); Pindobaçu, abr. 2006, V.J. Santos 508 (HUEFS); Poções, jan. 2009, P.D. Carvalho \& A.A. Conceição 456 (HUEFS); Porto Seguro, jul. 1984 G.L. Webster 25078 (HUEFS); Riachão do Jacuípe, jul. 1985, L.R. Noblick 4037 (HUEFS); Ribeira do Pombal, maio 1981, H.P. Bautista 386 (HRB); Ruy Barbosa, nov. 2004, L.P. Queiroz et al. 9717 (HUEFS); Salvador, dez. 1985, L.R. Noblick 4503 (HUEFS); São Gabriel, abr. 2009, R.F. Machado et al. 206 (HUEFS); Senhor do Bonfim, mar. 1974, R.M. Harley et al. 16623 (IPA); Serra Preta, jul. 1985, L.R. Noblick 4214 (HUEFS); Simões Filho, nov. 1999, E. Melo et al. 2899 (HUEFS).

Euphorbia hyssopifolia se assemelha a E. bahiensis, porém apresenta dicásios bastante ramificados, com eixos terminais laterais congestos, enquanto $E$. bahiensis possui dicásios pouco ramificados, sem eixos congestos.

17. Euphorbia insulana Vell., Fl. Flumin. 5: 202, tab. 14. 1825.

Figuras 11 e 12A-J.

Subarbustos eretos, ca. $2 \mathrm{~m}$ alt.; ramos não suculentos, eretos, cilíndricos, verdes, esparsamente pubescentes. Folhas alternas, passando a verticiladas no ápice dos ramos, membranáceas; limbo oval a lanceolado, 45-95 × 15-33 mm, ápice agudo a acuminado, base cuneada, margens inteiras, ciliadas, face abaxial pubescente, a adaxial glabra; pecíolo 4-12 $\mathrm{mm}$ compr.; estípulas oval-lanceoladas, $1-1,5 \mathrm{~mm}$ compr., pilosas. Ciátios zigomorfos, monoclinos, em dicásios; pedúnculo 1-4 $\mathrm{mm}$ compr.; brácteas lanceoladas, 1,5-2 × 1-1,5 mm, ápice acuminado, margens inteiras, pilosas; invólucro turbinado, 2-4 $\times$ 1,5-2 mm, glabros; lobos obovados, fimbriados, verdes; nectários 2, pateliformes, amarelo-esverdeados; apêndices bilabiados, cuneados; bractéolas obovais, fimbriadas, pilosas. Flores estaminadas ca. 20 por ciátio, ca. 1,5 mm compr.; pedicelo ca. 1,5 mm compr. Flores pistiladas ca. $2 \mathrm{~mm}$ compr.; ovário globoso, ca. $0,9 \times 1 \mathrm{~mm}$, pubescente; estiletes curtamente 2partidos, eretos, achatados; estigmas obtusos; pedicelo ca. $1 \mathrm{~mm}$ compr. Frutos globosos, 2-2,5 × 2-3 mm, pubescentes, amarelo-esverdeado; pedicelo $2-2,5 \mathrm{~mm}$ compr.; sementes castanhas, ovais, 2-2,5 × 1,5-2 mm, verrucosas, com carúncula.
Ocorre no litoral do Brasil, alcançando a Argentina (Subils 1977); no Brasil, é registrada para a Bahia, Ceará, Espírito Santo, Goiás, Minas Gerais, Pará, Paraná, Pernambuco, Rio de Janeiro, Santa Catarina, São Paulo e Sergipe. C7, D7, E7, E8, E9, F4, F7, F8 e K8: em restinga. Encontrada com flores ou frutos de março a dezembro.

Material selecionado - Alagoinhas, jan. 2001, N.G. Jesus et al. 530 (HUEFS); Bom Jesus da Lapa, fev. 2000, L.P. Queiroz et al. 5895 (HUEFS); Cachoeira, jul. 1980, Grupo Pedra do Cavalo 454 (CEPEC, HRB, HUEFS); Conceição de Feira, jul. 1980, L.R. Noblick 1949 (HUEFS); Cravolândia, maio 1994, F. França et al. 1057 (HUEFS); Feira de Santana, maio 1984, L.R. Noblick 3194 (CEPEC, HUEFS); Ipecaetá, ago. 1985, L.R. Noblick 4342 (HUEFS); Itaberaba, mar. 1999, R.M. Harley 53492 (HUEFS); Jacobina, jun. 1999, B.M. Silva et al. 5 (HUEFS); Maracás, set. 2011, E. Melo et al. 10557 (HUEFS); Milagres, out. 2012, E. Melo et al. 11535 (HUEFS); Mucuri, jul. 1978, E. Mori et al. 10536 (CEPEC); Tucano, jan. 2006, D. Cardoso et al. 931 (HUEFS); Ubaíra, mar. 2008, R.P. Oliveira et al. 1486 (HUEFS).

Euphorbia insulana pode ser reconhecida dentre as demais espécies do gênero que ocorrem na Bahia por apresentar apêndices dos ciátios bilabiados e dois nectários sésseis e pateliformes por ciátio. Silva et al. (2014) encontrou espécimes com até três nectários no ciátio, o que não foi registrado para a Bahia.

18. Euphorbia jablonskii V.W.Steinm., Contr. Univ. Michigan Herb. 25: 231. 2007.

Figura 11; Steinmann et al. (2007).

Arbustos eretos, 1,6-3,5 m alt.; ramos não suculentos; caule cilíndrico, com nós e internos nítidos, verde, glabro. Folhas alternas, passando a verticiladas no ápice dos ramos, membranáceas a cartáceas; limbo oval a elíptico-oblongo, $15-30 \times 10-15 \mathrm{~mm}$, ápice obtuso a mucronado, base simétrica, arredondada, margens inteiras, faces abaxial e adaxial glabras; pecíolo filiforme 6-10 $\mathrm{mm}$ compr., glabro; estípulas glanduliformes, glabras. Ciátios actinomorfos, monoclinos, solitários a congestos, axilares; pedúnculo 3-5 mm compr., pubérulo; brácteas ovais, 10-15 × 3-4 $\mathrm{mm}$, ápice agudo, margens inteiras; invólucro campanulado, 1,5-2 $\mathrm{mm}$ compr., pubérulo. amareloesverdeado; lobos ovais, margem lacerado-denteadas; nectários 5, oblongos, amarelo-esverdeados; apêndices palmados, 7-9-partidos, lacínios triangulares; bractéolas lineares, pubescentes. Flores estaminadas 30-40 por ciátio, 2-3 mm compr.; pedicelo 1-2 $\mathrm{mm}$ compr. Flor pistilada 3-4 $\mathrm{mm}$ compr., ovário subgloboso, ca. $1 \times 1 \mathrm{~mm}$, pubérulo; estiletes livres, ramos 2-partidos, patentes; estigmas obtusos; pedicelo ca. 2-3 mm compr. Frutos subglobosos, ca. $3 \times 2,5$ $\mathrm{mm}$, pubérulos a pubescentes, amarelo-esverdeadsos; pedicelo ca. 2,5 mm compr.; sementes castanhoescuras, ovais, 2,5-3 × 1,5-2 $\mathrm{mm}$, rugosas, sem carúncula.

Registrada para o Distrito Federal, sobre calcário (Steinmann et al. 2007), é aqui citada pela primeira vez para a Bahia. C/D6 e E6: caatinga, sobre 


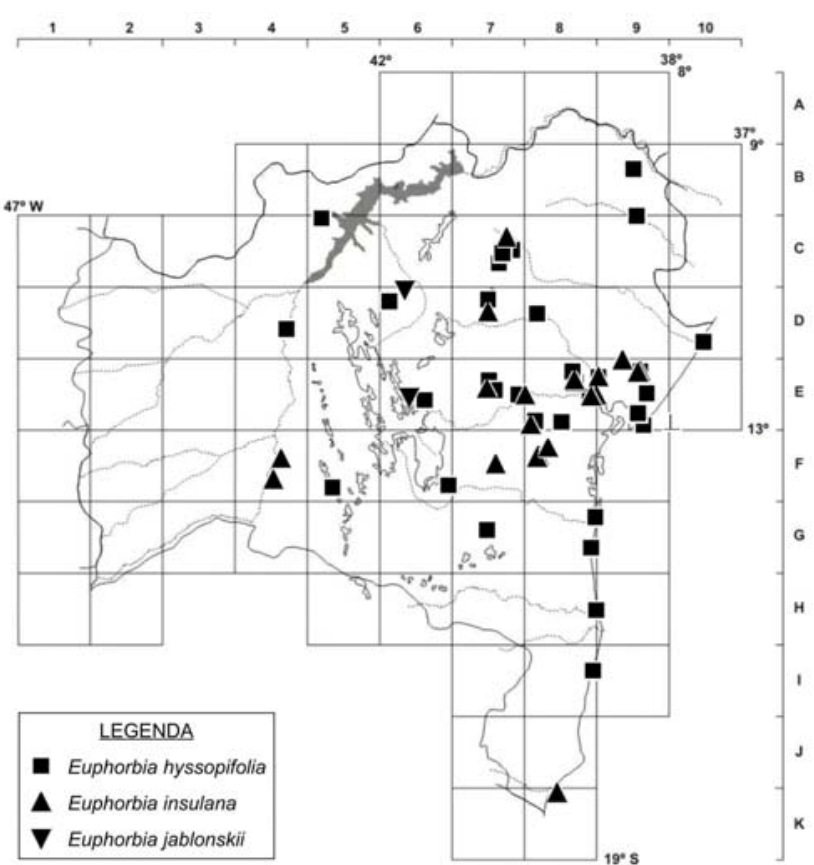

Figura 11. Mapa de distribuição geográfica de Euphorbia hyssopifolia, E. insulana e E. jablonskii no estado da Bahia.

afloramentos de calcário. Encontrada com flores ou frutos de novembro a abril.

Material selecionado - Palmeiras, mar. 2003, E. Melo et al. 3640 (HUEFS). São Gabriel, abr. 2009, R.F. Machado et al. 127 (HUEFS).

O material Melo 3640 (HUEFS 78059), citado por Lucena \& Alves (2010, e na Flora do Brasil 2020) como Euphorbia lycioides Boiss., se trata de E. jablonskii. Euphorbia lycioides é um arbustos com $1 \mathrm{~m}$ de altura, de ramos acinzentados e tomentosos, folhas sésseis, ciátios glabros com apêndices fimbriados e ovário glabro (vs. arbustos de 1,6-3,5 m de altura, ramos esverdeados, glabros, folhas pecioladas com 1 $\mathrm{cm}$ de comprimento, ciátios pubérulos com apêndices palmados, 7-9-partidos, e ovário pubérulo).

19. Euphorbia phosphorea Mart. in Martius \& Spix, Reise Bras. 2: 726. 1828.

Figuras $12 \mathrm{~K}-\mathrm{T}$ e 13.

Arbustos eretos, bem ramificados, até $4 \mathrm{~m}$ alt., cactiformes; cladódios suculentos, eretos, 8-costados, verdes, glabros, áfilos; estípulas não observadas. Ciátios actinomorfos, monoclinos, solitários ou em fascículos, axilares; brácteas largamente triangulares, 1,4-1,7 × 1,6-2 mm, ápice agudo, glabras; invólucro hemisférico, 4-5 × 3-4 mm, glabro; lobos largamente obovados, fimbriados, glabros, vináceos; nectários 5 , elípticos, vináceos; apêndices 2-partidos, corniculados, ápices encurvados, vináceos; bractéolas linearlanceoladas, fimbriadas, glabras. Flores estaminadas ca. 25 por ciátio, 2,5-5 mm compr.; pedicelo 1-3 mm compr. Flores pistiladas ca. $2,5 \mathrm{~mm}$ compr.; ovário globoso, ca. $1 \times 1 \mathrm{~mm}$, glabro; estiletes unidos até a metade, ramos inteiros, eretos; estigmas obtusos; pedicelo ca. $1 \mathrm{~mm}$ compr. Frutos globosos, 3,8-5 $\times$
4,7-6 mm, glabros, vináceos; pedicelo ca. $6 \mathrm{~mm}$ compr.; sementes castanhas, globosas, ca. $3 \times 3 \mathrm{~mm}$, lisas, com carúncula.

Referida por Rizzini (1989) para a porção central da Bahia, Paraíba e Sergipe. B8, B9, C6, D6, D8, D9, E7/8, E8, F6 e G5: caatinga, mata estacional e campo rupestre, em solo argilo-arenoso. Encontrada com flores e frutos entre março e novembro.

Material selecionado - Bendengó, jun. 2005, D.S. CarneiroTorres et al. 513 (HUEFS); Boa Nova, fev. 2013, L.C. Marinho et al. 402 (HUEFS); Gentio do Ouro, maio 2002, M.C. Ferreira et al. 1292 (HUEFS); Iaçu, fev. 2005, F. França et al. 5137 (HUEFS); Itaberaba, set. 1984, G. Hatschbach 48193 (CEPEC); Itatim, abr. 1996, F. França et al. 1597 (HUEFS); Jeremoabo, jun. 2007, D.S. Carneiro-Torres et al. 980 (HUEFS); Morro do Chapéu, set. 2004, E.L. Borba et al. 2042 (HUEFS); Santa Brígida, jul. 1983, L.P. Queiroz et al. 739 (HUEFS); Santo Sé, abr. 2002, K.R.B. Leite et al. 184 (HUEFS); Serra do Ramalho, abr. 2001, J.G. Jardim et al. 3474 (HUEFS); Serrolândia, ago. 1980, W. Fonseca 322 (HRB); Tucano, nov. 1993, L.P. Queiroz \& T.N. Sena 3110 (HUEFS); Uauá, mar. 2002. E. Saar et al. 12 (HUEFS); Umburanas, mar. 1974, R.M. Harley et al 16960 (IPA, RB); Sem Município, Morro do Couro ou Morro São Cristovão, mar. 1977, R.M. Harley 19423 (CEPEC).

Euphorbia phosphorea é um arbusto com cladódios 8-costados, ciátios monoclinos e apêndices corniculados. O epiteto "phosphorea" se refere à fosforescência do látex no escuro, a qual também observamos na região de Morro do Chapéu.

20. Euphorbia potentilloides Boiss., Cent. Euphorb.: 3. 1860.

Figuras 13 e $14 \mathrm{~A}-\mathrm{I}$.

Ervas eretas, até $0,2 \mathrm{~m}$ alt.; ramos vináceos, glabros. Folhas verticiladas, tornando-se opostas no ápice dos ramos, crasso-membranáceas; limbo linearlanceolado, oval a oblongo, 9-30 × 1-4 mm, ápice agudo, cuspidado a apiculado, base aguda, obtusa, truncada a levemente cordada, levemente assimétrica, margens inteiras, raramente espessadas, planas a levemente revolutas, faces abaxial e adaxial glabras; pecíolo 0,6-1,3 $\mathrm{mm}$ compr.; estípulas estreitas a largamente triangulares, ca. $1 \mathrm{~mm}$ compr., fimbriadas, glabras. Ciátios actinomorfos, em dicásios, terminais a raramente axilares; pedúnculos $0,6-1,6 \mathrm{~mm}$ compr.; invólucro campanulado, $1,5-3 \times 1-2,8 \mathrm{~mm}$, glabro externamente, viloso próximo aos nectários; lobos triangulares, margens inteiras, ciliadas, amareloesverdeados; nectários 4 ou 5(6), sésseis, arredondados a reniformes, amarelos; apêndices 4 ou 5(6), iguais, reniformes a oblongos, glabros, amareloesbranquiçados; bractéolas oval-lanceoladas, fimbriadas, pubescentes. Flores estaminadas ca. 25 por ciátio, ca. $1 \mathrm{~mm}$ compr.; pedicelo ca. $1,5 \mathrm{~mm}$ compr. Flores pistiladas $1-1,5 \mathrm{~mm}$ compr.; ovário globoso, ca. 0,6 $\times 0,9 \mathrm{~mm}$, glabro; estiletes unidos na base, ramos 2-partidos, patentes, glabros; estigmas clavados; pedicelo 1-1,5 mm compr. Frutos globosos, $2-2,5 \times 2-2,6 \mathrm{~mm}$, glabros, amarelo-esverdeados; 

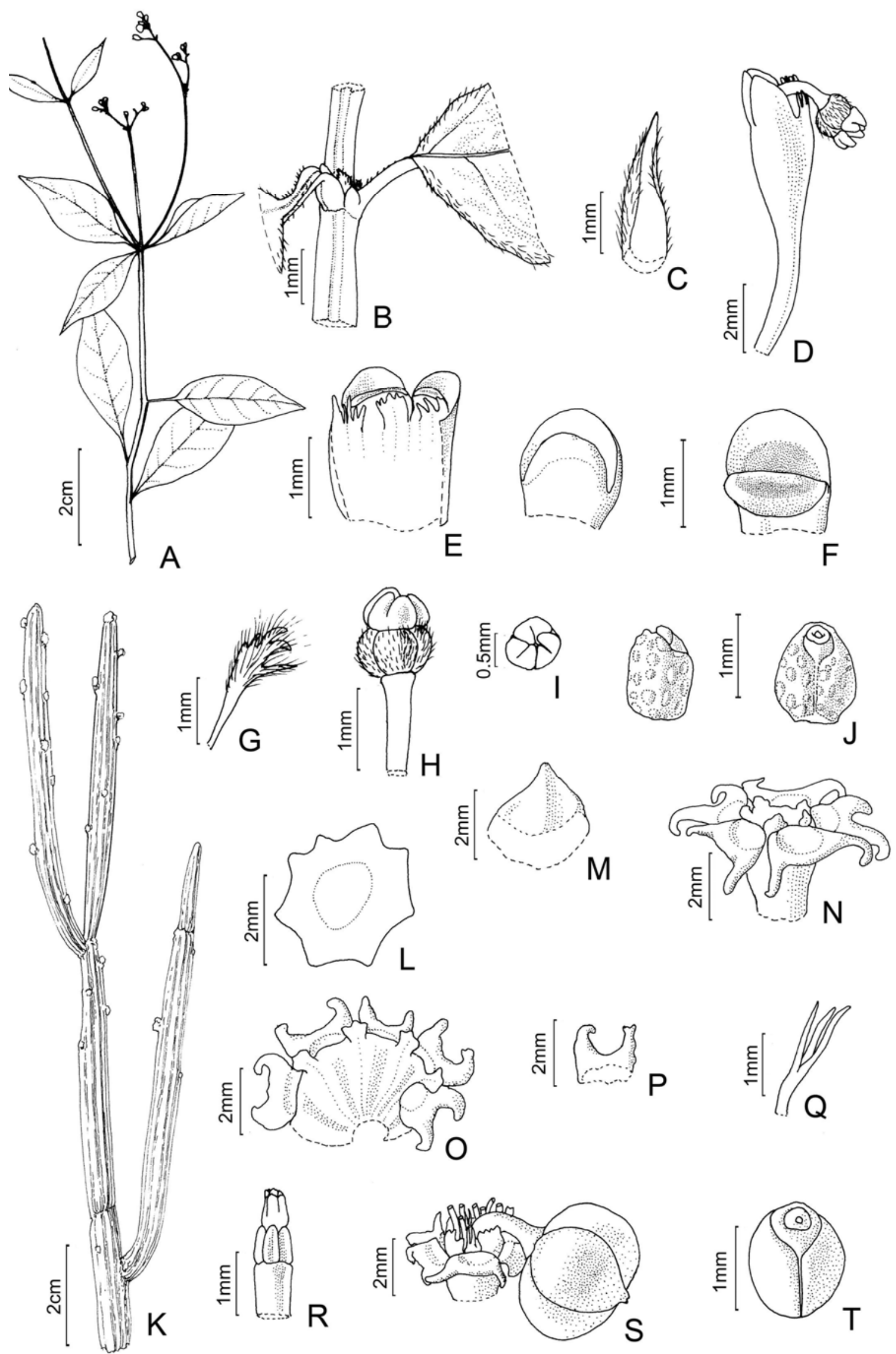

Figura 12. A-J. Euphorbia insulana: A- hábito; B- estípula; C- bráctea, face adaxial; D- ciátio; E- ciátio, corte longitudinal; F- apêndices e nectários, vista frontal; G- bractéola; H- flor pistilada; I- detalhe do estigma; J- sementes, vistas frontal (à direita) e lateral (à esquerda) (Silva 5). K-T. E. phosphorea: K- hábito; L- cladódio, corte longitudinal; M- bráctea, face adaxial; N- ciátio; O- ciátio, corte longitudinal; P-apêndice do ciátio; Q- bractéola; R- flor pistilada; S- ciátio com fruto; T- semente, vista frontal (França 2865). 
pedicelo ca. $4 \mathrm{~mm}$ compr.; sementes castanhas, ovais a subovoides, 1,2-1,5 × 0,7-1,1 mm, lisas, sem carúncula.

Ocorre na Argentina, Bolívia, Paraguai e Uruguai (Cordeiro 1995; Simmons \& Hayden 1997); no Brasil, é registrada para a Bahia, Distrito Federal, Goiás, Mato Grosso, Minas Gerais, Paraná, Rio Grande do Sul, São Paulo e Tocantins. B5/6, D1, D6, E2/3, F5, F6 e G5: cerrado de solo arenoso e pedregoso e outras formações abertas sujeitas à ação do fogo, o qual influência seu ciclo de vida, funcionando como estímulo para o brotamento e floração. Encontrada com flores ou frutos de setembro a junho.

Material selecionado - Abaíra, nov. 1992, W. Ganev 1006 (HUEFS); Barreiras, jan. 2004, M. Machado \& M.V.M. Oliveira 77 (HUEFS); Barra da Estiva, fev. 1997, B. Stannard et al. PCD 5745 (CEPEC, HRB, HUEFS); Caetité, abr. 1980, R.M. Harley 21153 (CEPEC; SPF); Coribe, jan. 2004, M. Machado \& M.V.M. Oliveira 145 (HUEFS); Érico Cardoso, jan. 2008, A. Rapini et al. 1523 (HUEFS); Morro do Chapéu, maio 1999, F. França et al. 2819 (CEPEC, HUEFS); Mucugê, dez. 1998, R.P. Oliveira et al. 48 (HUEFS); Palmeiras, dez. 1994, M.L. Guedes et al. PCD 1459 (CEPEC, HUEFS); Piatã, nov. 1996, L.P. Queiroz et al. PCD 3943 (ALCB); Rio de Contas, set. 1981, J.R. Pirani et al. CFCR 2163 (CEPEC, SPF); São Desidério, maio 2010, E. Melo et al. 8129 (HUEFS); Sento Sé, jan. 2008, C. Correia et al. 405 (HUEFS).

Euphorbia potentilloides é geralmente tratada como E. caecorum Mart. ex Boiss., cujo epíteto está vinculado a Anisophyllum caecorum, publicado por Klotzsch \& Garcke em 1859, um "nomen nudum" (Simmons \& Hayden 1997). A espécie difere do restante do gênero na Bahia por apresentar ciátios glabros, com apêndices de mesmo tamanho e forma. Euphorbia viscoides e E. tamanduana, espécies mais semelhantes a ela, apresentam ciátios hirsuto-velutinos a curto-pubescentes e apêndices com formas e tamanhos diferentes. Euphorbia potentilloides possui uma grande variação na forma das folhas, podendo ser linear-lanceolada, oval ou oblonga, com ápice agudo, cuspidado ou apiculado na mesma população. Outra característica diagnóstica desta espécie é a base da folha levemente assimétrica.

21. Euphorbia prostrata Aiton, Hort. Kew 2: 139. 1789.

Figuras 13 e 14J-S.

Ervas prostradas; ramos vináceos, puberulentos. Folhas opostas, membranáceas, acródromas; limbo oblongo a elíptico, 4-8 × 3-4,5 $\mathrm{mm}$, ápice obtuso a arredondado, base assimétrica, margens serradas; face abaxial puberulenta, a adaxial esparsamente vilosa; pecíolo ca. $1 \mathrm{~mm}$ compr.; estípulas triangulares, 0,7-1 mm compr., fimbriadas, glabras. Ciátios actinomorfos, solitários a geminados, axilares; pedúnculos 1-2 mm compr.; invólucro obcônico, ca. $1 \times 0,7 \mathrm{~mm}$, glabro; lobos triangulares, margens inteiras, ciliadas, esverdeados; nectários 4, estipitados, suborbiculares, amarelados; apêndices 4, iguais, subelípticos, glabros, amarelo-esbranquiçados; bractéolas ausentes. Flores estaminadas ca. 5 por ciátio, ca. 1,5 mm compr.;

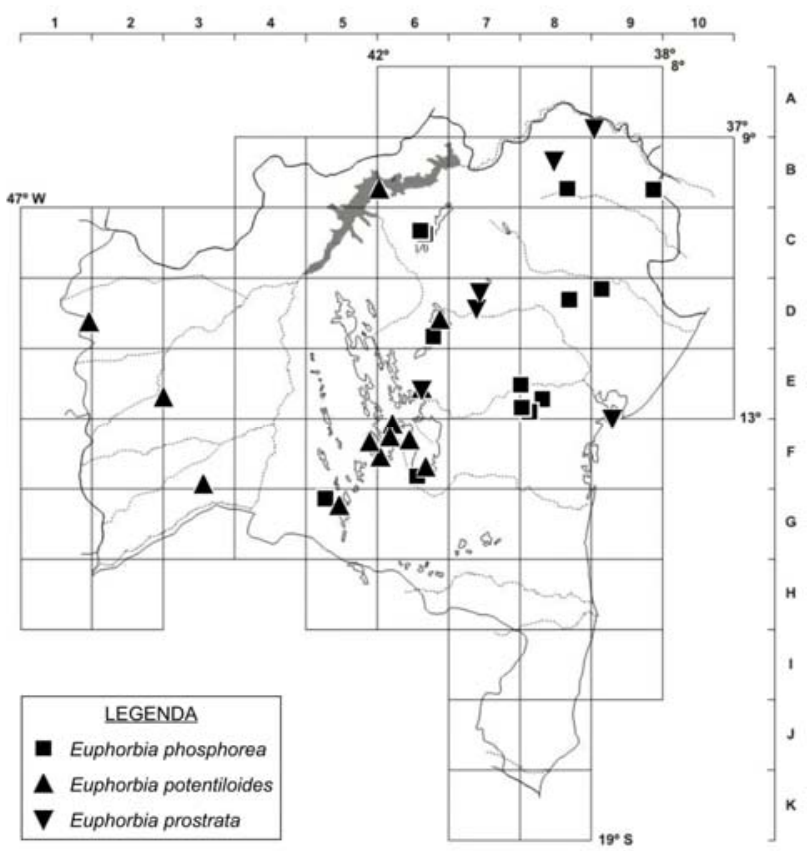

Figura 13. Mapa de distribuição geográfica de Euphorbia phosphorea, E. potentilloides e E. prostrata no estado da Bahia.

pedicelo ca. 0,7 mm compr. Flores pistiladas $1-1,5$ $\mathrm{mm}$ compr.; ovário globoso, 0,5-0,8 × 0,5-0,8 mm, com tricomas ao longo dos septos e glabro na superfície restante; estiletes unidos na base, ramos 2partidos, patentes, glabros; estigmas capitados; pedicelo 0,5-1 $\mathrm{mm}$ compr. Frutos globosos, 1-1,5 $\times$ 1,2-1,4 mm, com tricomas apenas ao longo dos septos, glabro no restante, castanho-avermelhados; pedicelo 1$1,5 \mathrm{~mm}$ compr.; sementes castanhas, ovais, $0,8-1 \times$ 0,4-0,5 mm, com 4-8 costelas transversais estreitas, sem carúncula.

Espécie ruderal, com distribuição pantropical (Steinmann \& Porter 2002); no Brasil, ocorre na Bahia, Ceará, Distrito Federal, Maranhão, Mato Grosso do Sul, Minas Gerais, Paraíba, Paraná, Pernambuco, Rio de Janeiro, Rio Grande do Sul, Santa Catarina e São Paulo. A8/9, B8, D7, E6 e E9: crescendo entre rochas, nos canteiros e margens dos gramados. Encontradas com flores ou frutos o ano todo.

Material selecionado - Curaça, mar. 2011, E. Melo et al. 9422 (HUEFS); Lençóis, mar. 1984, L.R. Noblick 2993 (CEPEC, HUEFS); Miguel Calmon, jun. 1985, L.R. Noblick 3913 (HUEFS); Vera Cruz, fev. 1990, G.C.P. Pinto 03/90 (HUEFS); Rodelas, out. 2009, E. Melo et al. 7019 (HUEFS).

Euphorbia prostrata é semelhante a $E$. chamaeclada, mas possui indumento puberulento (vs. ramos glabros em E. chamaeclada), nectários estipitados (vs. sésseis) e cinco flores estaminadas por ciátio (vs. 20).

22. Euphorbia sarcodes Boiss., Cent. Euphorb.: 29.1860 .

Figuras 15 e $16 \mathrm{~A}-\mathrm{K}$.

Arbustos eretos, ca. $0,5 \mathrm{~m}$ alt.; ramos jovens suculentos, decumbentes, cilíndricos, verdes, glabros. 

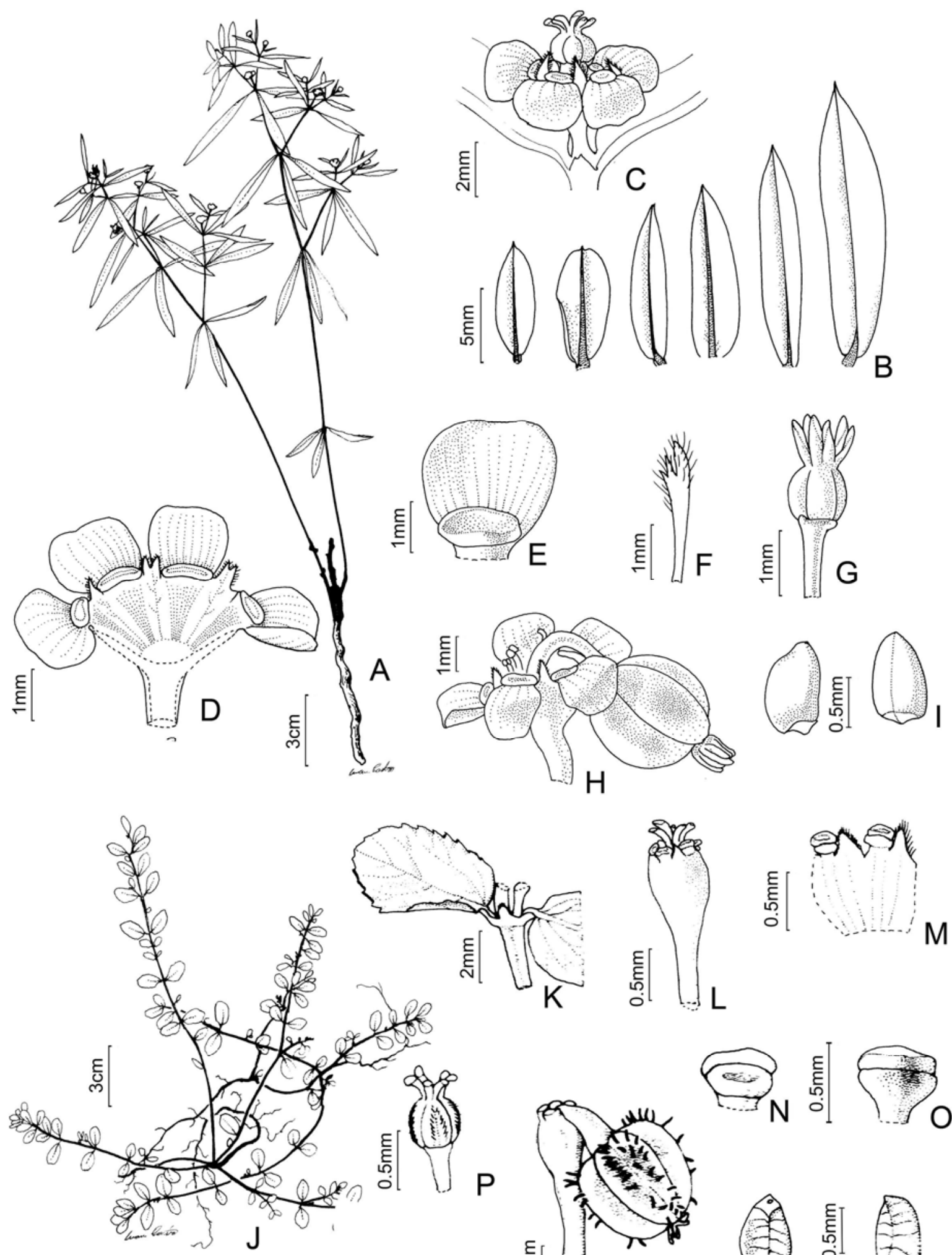

Figura 14. A-I. Euphorbia potentilloides: A- hábito; B- variação na forma das folhas em face adaxial; C- ciátio; D- ciátio, corte longitudinal; E- apêndice e nectário, vista frontal; F- bractéola; G- flor pistilada; H- ciátio com fruto; I- sementes, vistas frontal (à direita) e lateral (à esquerda) (Ganev 1006). J-S. E. prostrata: J- hábito; K- folha e estípula; L- ciátio; M- ciátio, corte longitudinal mostrando 2 nectários; N- nectário, vista frontal; O- nectário, vista dorsal; P- flor pistilada; Q- ciátio com fruto; R- semente, vista frontal; S- semente, vista lateral (Noblick 2993). 
Folhas sésseis a subsésseis, alternas, passando a verticiladas no ápice dos ramos, membranáceas, uninérvias; limbo espatulado, 18-38 × 3-5 mm, ápice arredondado, base atenuada a levemente cuneada, margens inteiras, face abaxial glabra, a adaxial pilosa na base, próximo à inserção com o caule; estípulas glanduliformes, glabras. Ciátios actinomorfos, monoclinos, em umbelas compostas, terminais; pedúnculo 1-1,5 $\mathrm{mm}$ compr.; brácteas orbiculares a arredondadas, 6,5-10 × 4,5-7 mm, ápice cuspidado, margens inteiras; invólucro campanulado, 2-4 × 2-3 $\mathrm{mm}$, glabro; lobos triangulares, margens inteiras, ciliadas, amarelo-esverdeados; nectários 4, elípticos, verdes; apêndices palmados, 4-6-partidos, lacínios linear-lanceolados, brancos; bractéolas lanceoladas, glabras. Flores estaminadas 20 por ciátio, 4-5 mm compr.; pedicelo 2,5-3 mm compr. Flores pistiladas ca. $6 \mathrm{~mm}$ compr.; ovário subgloboso, ca. 1,5 × 1,4 mm, glabro; estiletes unidos até a metade, ramos indivisos, patentes; estigmas obtusos; pedicelo ca. 2,5 $\mathrm{mm}$ compr. Frutos subglobosos, ca. 4,3 × 4,2 mm, glabros, amarelo-esverdeados; pedicelo 4-4,5 $\mathrm{mm}$ compr.; sementes castanhas, ovais, ca. $3 \times 2,6 \mathrm{~mm}$, verrucosas, carunculadas.

Ocorre na Bahia, Minas Gerais, Pernambuco e Sergipe. C6 e D6: campo rupestre, sobre solo arenoso. Encontrada com flores ou frutos em janeiro, abril, agosto, outubro e novembro.

Material selecionado - Morro do Chapéu, mar. 2003, L.P. Queiroz et al. 7732 (HUEFS); Sento Sé, jun. 1985, G. Fotius 4076 (HUEFS); Umburanas, jun. 2004, M. Machado 226 (HUEFS).

Euphorbia sarcodes pode ser facilmente diferenciada das demais espécies do gênero na Bahia por apresentar folhas espatuladas, invólucro do ciátio campanulado, apêndices 4-6-palmados e 20 flores estaminadas no ciátio. É semelhante a E. goyazensis, que no entanto não possui ramos suculentos, cujas folhas são lanceoladas a linear-lanceoladas e o invólucro do ciátio é turbinado.

23. Euphorbia sciadophila Boiss., Prodr. 15(2): 57. 1862.

Figura 15.

Ervas eretas, até 0,9 m alt.; ramos não suculentos, eretos; caule cilíndrico, verde, esparsamente puberulento. Folhas alternas, passando a verticiladas no ápice dos ramos, membranáceas; limbo oval a orbicular, 20-23 × 15-18 mm, ápice acuminado, base obtusa a largo-truncado, margens inteiras, face abaxial pubérula, a adaxial glabra; pecíolo filiforme 10-40 mm compr., pubescente; estípulas glanduliformes, pubérulas. Ciátios actinomorfos, monoclinos, dicásios, terminais; pedúnculo $10 \mathrm{~mm}$ compr.; brácteas ovallanceoladas, 10-15 × 3-4 mm, ápice agudo, margens inteiras; invólucro turbinado, 1,5-2 $\mathrm{mm}$ compr., hirsuto externamente, amarelo-esverdeado; lobos ovais, margens lacerado-denteadas; nectários 4, elípticos, amarelo-esverdeados; apêndices palmados, 2-4partidos, lacínios estreito-triangulares, digitiformes; bractéolas lineares, pubescentes. Flores estaminadas 5-10 por ciátio, 2-4 mm compr.; pedicelo 1,5-3 $\mathrm{mm}$ compr. Flores pistiladas $3-4 \mathrm{~mm}$ compr.; ovário subgloboso, ca. $1 \times 1 \mathrm{~mm}$, pubérulo; estiletes unidos até a metade, ramos 2-partidos, patentes; estigmas obtusos; pedicelo 2-3 mm compr. Frutos globosos, ca. $3 \times 2,5 \mathrm{~mm}$, pubérulos a pubescentes, amareloesverdeados; pedicelo ca. $3 \mathrm{~mm}$ compr.; sementes castanho-escuras, ovais, ca. $3 \times 2 \mathrm{~mm}$, faveolada, carúncula inconspícua.

Ocorre na Argentina, Bolívia, Brasil, Paraguai e Uruguai; no Brasil, é registrada para o Ceará, Goiás, Maranhão, Mato Grosso, Mato Grosso do Sul, Minas Gerais, Pará, Paraná, Santa Catarina, São Paulo e Rio Grande do Sul. D2, E6/7, E8 e F6: mata ciliar na região de cerrado. Encontrada com flores e frutos de janeiro a maio.

Material selecionado - Barreiras, jan. 2009, B.T.C. Santos et al. 329 (HUEFS); Formosa do Rio Preto, mar. 2000, R.M. Harley et al. 53789 (HUEFS); Ibiquera, maio 2004, F. França et al. 4959 (HUEFS); Ipirá, s.d., L.P. Queiroz et al. 10611 (HUEFS); Rio de Contas, mar. 2004, R.M. Harley et al. 55035 (HUEFS).

Material adicional - BRAZIL. MINAS GERAIS: Januária, maio 1997, A. Salino 3073 (HUEFS).

Euphorbia sciadophila pode ser distinta das demais espécies de Euphorbia da Bahia por apresentar folhas ovais a orbiculares, pecioladas, com $10-40 \mathrm{~mm}$ de comprimento, e ciátios com apêndices palmados de 2 a 4 por ciátio.

\section{Euphorbia serpens Kunth, Nov. Gen. Sp. (quarto ed.) 2: 52.1817 .}

Figura 15.

Ervas prostradas; ramos verdes a amarelados, glabros. Folhas opostas, membranáceas, acródromas; limbo orbicular, $0,3-0,5 \times 0,3-0,4 \mathrm{~mm}$, ápice arredondado, base assimétrica, margens inteiras, faces abaxial e adaxial glabras; pecíolo ca. $1 \mathrm{~mm}$ compr.; estípulas triangulares, ca. $1 \mathrm{~mm}$ compr., fimbriadas, glabras. Ciátios actinomorfos, solitários a geminados, axilares; pedúnculos 1-2 $\mathrm{mm}$ compr.; invólucro campanulado, 0,6-0,8 × 0,6-0,8 mm, glabro; lobos triangulares, margens ciliadas, esverdeados; nectários 4, elipsoides, vermelhos a púrpura; apêndices 4, iguais, reniformes, glabros, brancos; bractéolas ausentes. Flores estaminadas ca. 5 por ciátio, ca. 1,5 mm compr., pedicelo ca. $0,7 \mathrm{~mm}$ compr. Flores pistiladas 1-1,5 mm compr.; ovário globoso, 0,3-0,5 × 0,3-0,5 $\mathrm{mm}$, glabros; estiletes unidos na base, ramos 2partidos, patentes, glabros; estigmas capitados; pedicelo 0,5-1 mm compr. Frutos globosos, 1-1,5 × 1,2-1,5 mm, glabros, verdes a amarelados; pedicelo ca. $1 \mathrm{~mm}$ compr.; sementes castanhas, ovais, ca. $1 \times 0,5$ $\mathrm{mm}$, sem costelas transversais, sem carúncula.

Amplamente distribuída nas regiões tropicais e subtropicais; no Brasil, ocorre na Bahia, Goiás, Mato grosso, Mato Grosso do Sul, Minas Gerais, Paraíba, Paraná, Pernambuco, Rio de Janeiro, Rio Grande do Sul, Santa Catarina e São Paulo. D7: crescendo entre 


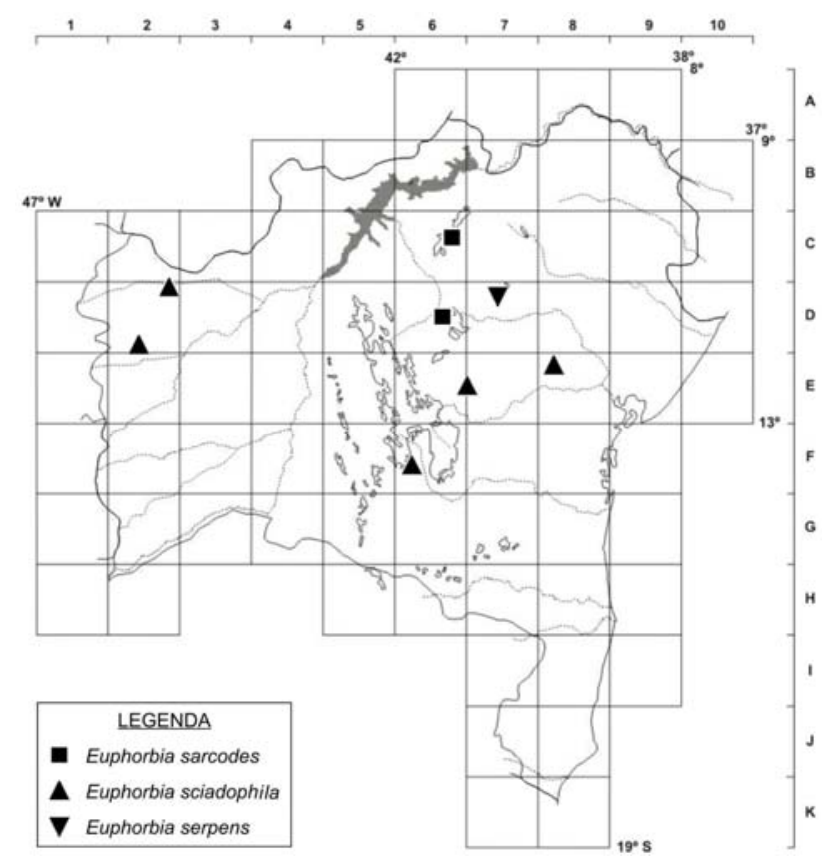

Figura 15. Mapa de distribuição geográfica de Euphorbia sarcodes, E. scyadophila e E. serpens no estado da Bahia.

rochas nos canteiros e em áreas antropizadas. Encontrada com flores ou frutos entre setembro e abril.

Material selecionado - Jacobina, nov. 1999, E. Melo et al. 2996 (HUEFS).

Material adicional - BRAZIL. PERNAMBUCO: Ilha de Fernando de Noronha, out. 1997, A.M. Miranda et al. 2874 (HST, HUEFS).

Euphorbia serpens é semelhante a E. prostrata por ambas apresentarem o hábito prostrado, porém difere pelos ramos totalmente glabros (vs. ramos puberulentos, em E. prostrata), apêndices dos ciátios iguais (vs. desiguais) e sementes sem costelas (vs. com 4-8 costelas transversais).

25. Euphorbia sessilifolia Klotzch ex Boiss., Prodr. 15(2): 64. 1862.

Figuras 16L-W e 17.

Ervas eretas, até $0,3 \mathrm{~m}$ alt.; ramos suculentos, eretos, cilíndricos, verdes, pubérulos. Folhas sésseis, espiraladas, passando a verticiladas no ápice dos ramos, cartáceas, uninérvias; limbo lanceolado a ovallanceolado, 10-30 × 3-6 mm, ápice acuminado a agudo, base atenuada, margens inteiras a serradas na metade superior, face abaxial com tricomas ao longo de toda a nervura, face adaxial pilosa na base, próximo à inserção com o caule; estípulas glanduliformes, pubérulas. Ciátios actinomorfos, monoclinos, solitários, terminais; pedúnculo 1,5-2 mm compr.; brácteas oval-lanceoladas, 10-20 × 3-4 mm, ápice agudo, margens inteiras; invólucro turbinado, 3-4,5 × 3,5-5,5 mm, pubérulo; lobos obovados, margens fimbriadas, amareloesverdeados; nectários 4, elípticos, verdes passando a purpúreos; apêndices palmados, 8- ou 9-partidos, lacínios linear-lanceolados, brancos passando a vermelhos; bractéolas lanceoladas, pubescentes. Flores estaminadas 20 por ciátio, 2,5-5 mm compr.; pedicelo 1,5-4 mm compr. Flores pistiladas 3-4 mm compr.; ovário subgloboso, 1,2-2 × 1-2 mm, pubérulo; estiletes unidos até a metade, ramos indivisos, eretos; estigmas obtusos; pedicelo ca. $1 \mathrm{~mm}$ compr. Frutos subglobosos, ca. $5 \times 5 \mathrm{~mm}$, pubérulos, amarelo-esverdeados; pedicelo ca. 3,5 mm compr.; sementes castanhos-escuras, obovadas, ca. $3,2 \times 2 \mathrm{~mm}$, verrucosas, com carúncula.

No Brasil, ocorre em Goiás e na Bahia. D6, E6 e F6: campo rupestre, em solo argilo-arenoso com afloramentos rochosos areníticos. Encontrada com flores ou frutos praticamente o ano todo, especialmente de março a junho.

Material selecionado - Abaíra, jan. 2006, T.S. Nunes et al. 1484 (HUEFS); Barra da Estiva, jan. 1974, R.M. Harley 15721 (CEPEC); Ibicoara, jan. 2005, R. Funch 527 (HUEFS); Jussiape, mar. 1999, R.M. Harley 53543 (HUEFS); Lençóis, nov. 2011, I. Cordeiro et al. 3389 (HUEFS); Morro do Chapéu, abr. 2000, I. Cordeiro et al. 2218 (HUEFS, SP); Mucugê, dez. 2007, P.L. Ribeiro et al. 252 (HUEFS); Palmeiras, jan. 2012, G. Almeida-Silva et al. 103 (HUEFS); Piatã, nov. 1996, D.J.N. Hind \& H.P. Bautista PCD 4128 (ALCB, HRB, HUEFS).

Esta espécie é caracterizada por apresentar ramos pubérulos, ciátios solitários, com invólucro turbinado e apêndices palmados 8- ou 9-partidos.

26. Euphorbia tamanduana Boiss., Cent. Euphorb.: 4. 1860.

Figuras 17 e $18 \mathrm{~A}-\mathrm{J}$.

Ervas eretas ou escandentes, ca. 0,4 m alt.; ramos avermelhados, densamente velutinos, tricomas multicelulares. Folhas opostas, papiráceas; limbo oval a elíptico, 14-18,6 × 7-9,4 mm, ápice obtuso a arredondado, base assimétrica, margens inteiras, faces abaxial e adaxial densamente velutinas; pecíolo 1-2 mm compr.; estípulas triangulares, 0,8-1 mm compr., fimbriadas no ápice, pilosas. Ciátios zigomorfos, solitários ou em dicásios, terminais; pedúnculos ca. 3 mm compr.; invólucro campanulado a hemisférico, 22,5 $\times$ 2-3 mm, externamente curto-pubescente e na base dos nectários pubescente; lobos triangulares, margens inteiras, ciliadas, amarelo-esverdeados; nectários 4, sésseis, transversalmente elípticos a oblongos, amarelados; apêndices 4, desiguais, 2 menores ovais, 2 maiores arredondados a pandurados, pubescentes nas 2 faces, brancos; bractéolas lanceoladas, fimbriadas, pubescentes. Flores estaminadas $20-25$ por ciátio, ca. $3 \mathrm{~mm}$ compr.; pedicelo ca. $2 \mathrm{~mm}$ compr. Flores pistiladas ca. 3,5 $\mathrm{mm}$ compr.; ovário globoso, ca. $1 \times 1 \mathrm{~mm}$, velutino; estiletes unidos na base, ramos 2-partidos, pubescentes, patentes; estigmas clavados; pedicelo ca. $2 \mathrm{~mm}$ compr. Frutos globosos, ca. 2,5 × 2,6 mm, pubescentes, amarelo-esverdeados; pedicelo ca. 2,5 mm compr.; sementes castanhas, ovais a subovais, 1,8-2 × 1-1,3 $\mathrm{mm}$, com 4 ou 5 costelas transversais, sem carúncula.

Endêmica da Bahia, ocorre apenas na porção norte do estado. C6 e D6: cerrado e campo rupestre. Encontrada com flores ou frutos de março a abril. 


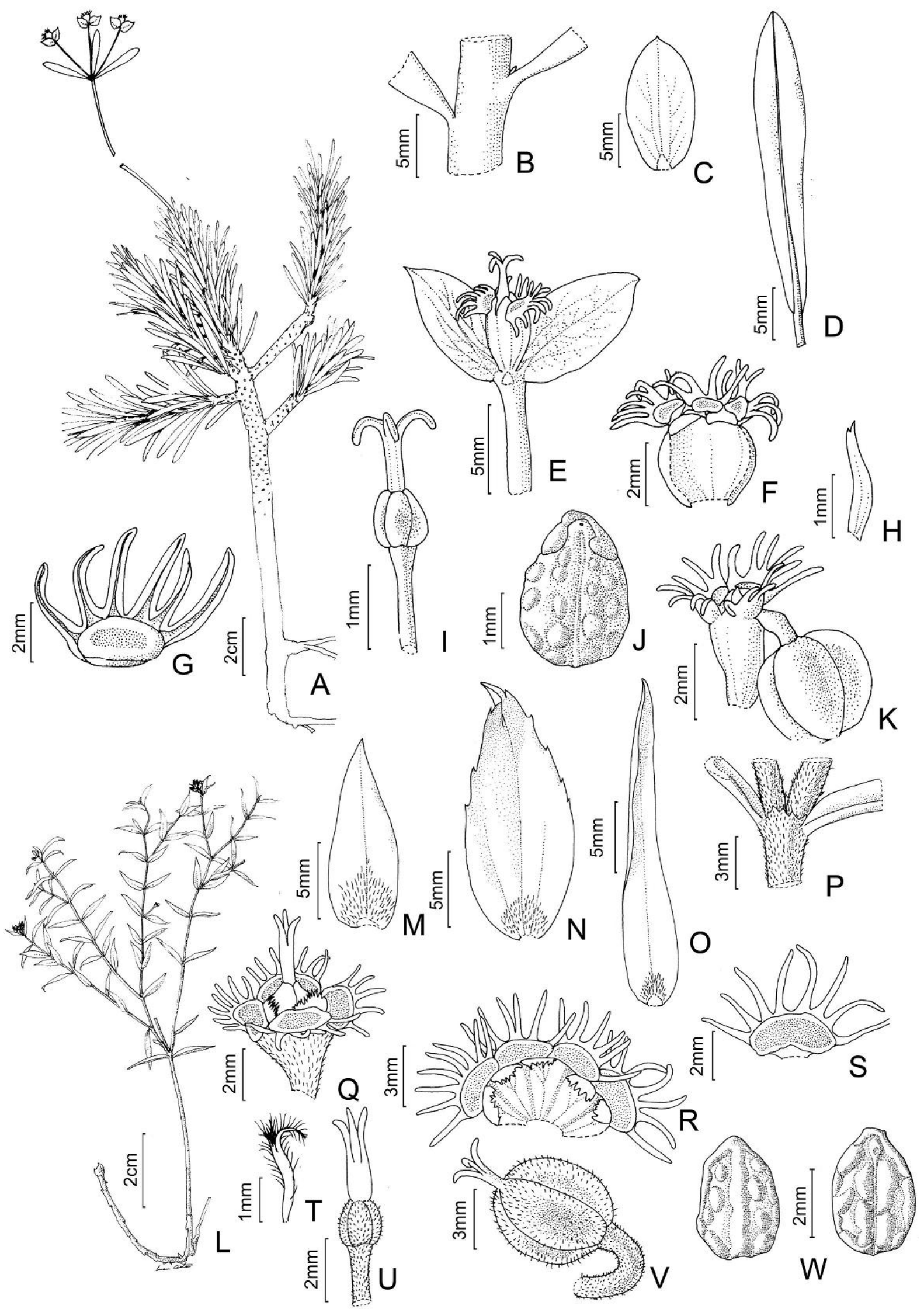

Figura 16. A-K. Euphorbia sarcodes: A- hábito; B- estípula; C- folha, face adaxial; D- bráctea; E- ciátio e brácteas; F- ciátio, corte longitudinal; G- apêndice e nectário, vista frontal; H- bractéola; I- flor pistilada; J- semente, vista frontal; K- ciátio com fruto (CarneiroTorres 173). L-W. E. sessilifolia: L- hábito; M- bráctea, face adaxial; N, O- folhas, face adaxial; P- estípula; Q- ciátio; R- ciátio, corte longitudinal; S- apêndice e nectário, vista frontal; T- bractéola; U- flor pistilada; V-fruto; W- sementes, vistas dorsal (à esquerda) e frontal (à direita) (França 2816). 
Material selecionado - Morro do Chapéu, maio 2007, D.S. Carneiro-Torres et al. 912 (HUEFS); Umburanas, mar. 1974, R.M. Harley 16831 (CEPEC).

Euphorbia tamanduana era conhecida apenas pelo material-tipo, coletado em Jacobina por Blanchet 3841 (Simmons \& Hayden 1997), tendo sido recoletada depois de mais de 100 anos. Assemelha-se a E. viscoides, da qual difere por possuir os apêndices do ciátio pubescentes nas duas faces (vs. glabros, em $E$. viscoides)

27. Euphorbia teres M.Machado \& Hofacker, Kakteen And. Sukk. 59: 150. 2008.

Figura 17.

Subarbustos eretos, 0,3-0,5 m alt., cactiformes; cladódios 3(4)-verticilados, suculentos, eretos, articulados, cilíndrico, verdes com ápices vináceos, glabros, áfilos; estípulas triangulares, ca. $1 \mathrm{~mm}$ compr., agudas, glabras. Ciátios actinomorfos, monoclinos, solitários a geminados, terminais, sésseis a subsésseis; brácteas lanceoladas, $1-1,5 \mathrm{~mm}$ compr., fimbriadas; invólucro turbinado, $1-1,5 \times 0,6-1 \mathrm{~mm}$, glabro; lobos oval-lanceolados, fimbriados, glabros, amareloesverdeados; nectários 5, transversalmente elípticos, branco-amarelados; apêndices 5, elípticos, irregularmente denteados, amarelo-esverdeados, glabros; bractéolas lanceoladas, pubescentes. Flores estaminadas 20 por ciátio, 1,5-2 mm compr.; pedicelo 1-1,5 mm compr. Flores pistiladas 1,5-2 mm compr.; ovário globoso, ca. $1 \times 1,5 \mathrm{~mm}$, glabro; estiletes unidos na base, ramos 2-partidos, patentes; estigmas obtusos; pedicelo 0,5-1 mm compr. Frutos globosos, 2-4 × 2-4 $\mathrm{mm}$, glabros, avermelhados; pedicelo ca. $2 \mathrm{~mm}$ compr.; sementes castanho-escuras, ovais, ca. $2 \times 2 \mathrm{~mm}$, sem ornamentação, com carúncula inconspícua.

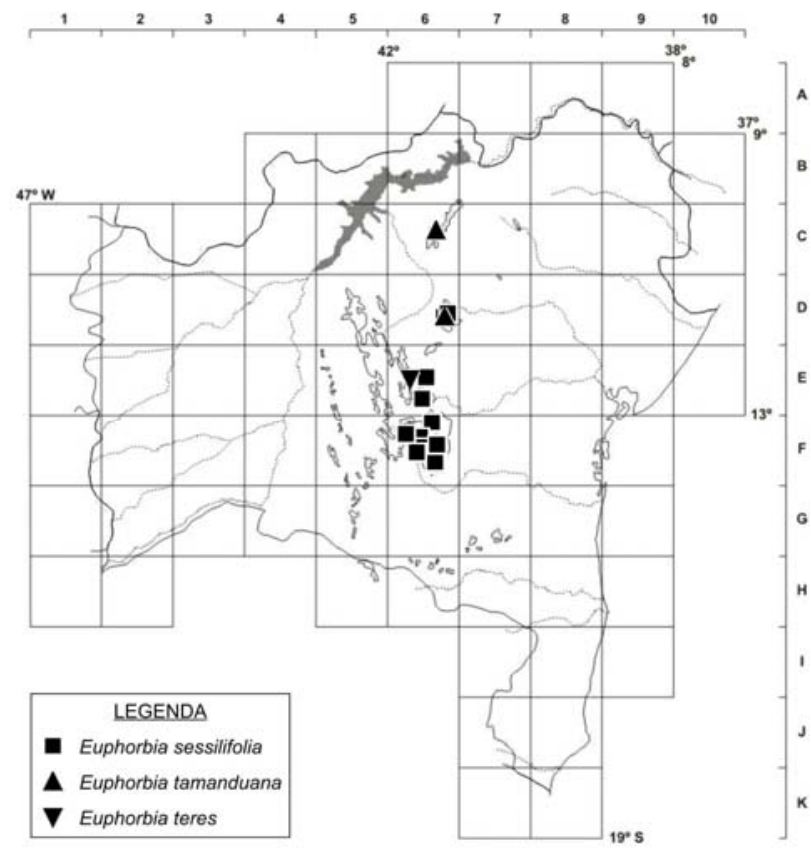

Figura 17. Mapa de distribuição geográfica de Euphorbia sessilifolia, E. tamanduana e E. teres no estado da Bahia.
Endêmica da Bahia. E6: campo rupestre. Encontrada com flores e frutos em fevereiro.

Material examinado - Seabra, estrada para Iraquara, afloramento de arenito, fev. 2006, M. Machado 772 (HUEFS).

Euphorbia teres é semelhante a E. flaviana quanto ao hábito, devido ao aspecto cactiforme, com cladódios cilíndricos e verticilados, mas difere por apresentar ramos adultos com 3(4) verticilos (vs. 6-14 verticilos), ciátios com apêndices elípticos (vs. sem apêndices) e estiletes patentes (vs. recurvados).

\section{Euphorbia thymifolia L., Sp. P1. 1: 454. 1753. Figura 19.}

Ervas prostradas; ramos vináceos, pubescentes. Folhas opostas, membranáceas, actinódromas; limbo elíptico, 3-8 × 2-4 mm, ápice obtuso a agudo, base assimétrica, margens planas, irregularmente serreadas, face abaxial glabra, a adaxial esparsamente pilosa a pubescente; pecíolo 0,5-1,0 $\mathrm{mm}$ compr.; estípulas triangulares, 0,5-1 $\mathrm{mm}$ compr., fimbriadas, glabras. Ciátios actinomorfos, solitários a geminados, axilares, aglomerados em ramos laterais congestos; pedúnculo 1-2 mm compr.; invólucro turbinado, 0,8-1 × 0,3-0,5 $\mathrm{mm}$, pubescente; lobos triangulares, margens inteiras, ciliadas, esverdeados; nectários 4, elipsoidais, vermelhos, sem apêndices ou, quando presentes, petaloides, reniformes, pouco desenvolvidos, glabros; bractéolas ausentes. Flores estaminadas ca. 5 por ciátio, ca. 1,5 mm compr.; anteras amarelas; pedicelo ca. $0,5 \mathrm{~mm}$ compr. Flores pistiladas $1-1,5 \mathrm{~mm}$ compr.; ovário globoso, 0,2-0,4 × 0,2-0,4 $\mathrm{mm}$, pubescente, avermelhado; estiletes unidos na base, ramos 2-partidos apenas no ápice, delgados, glabros; estigma capitados; pedicelo 0,5-1 mm compr. Frutos globosos, 1-1,3 $\times 1-1,3 \mathrm{~mm}$, pubescentes, avermelhados; pedicelo 1-1,3 mm compr.; sementes castanhas, ovais, $0,5-1 \times 0,3-0,5 \mathrm{~mm}$, com 2-4 costelas transversais estreitas, sem carúncula.

Amplamente distribuída nas regiões tropicais e subtropicais; no Brasil, ocorre em Alagoas, Amapá, Amazonas, Bahia, Ceará, Goiás, Maranhão, Mato Grosso, Mato Grosso do Sul, Minas Gerais, Pará, Paraíba, Piauí, Pernambuco, Rio de Janeiro e São Paulo. B9, C7, E/F9 e G3: formações abertas ou áreas antropizadas. Encontrada com flores e frutos durante todo o ano.

Material selecionado - Campo Formoso, abr. 1985, G. Fotius 3969 (HUEFS, HTS); Curaçá, fev. 1983, G. Fotius 3350 (HUEFS); Feira da Mata, abr. 2001, J.G. Jardim et al. 3595 (HUEFS); Vera Cruz, fev. 2002, M.V. Moraes 497 (HUEFS).

Euphorbia thymifolia é semelhante vegetativamente a E. adenoptera, porém apresenta ciátios sem apêndices ou, quando presente, não desenvolvidos, enquanto $E$. adenoptera possui ciátio com apêndices bem desenvolvidos. É comumente identificada como E. prostrata, da qual difere pela presença de tricomas restritos ao septo dos frutos, enquanto o fruto de $E$. thymifolia é pubescente. 


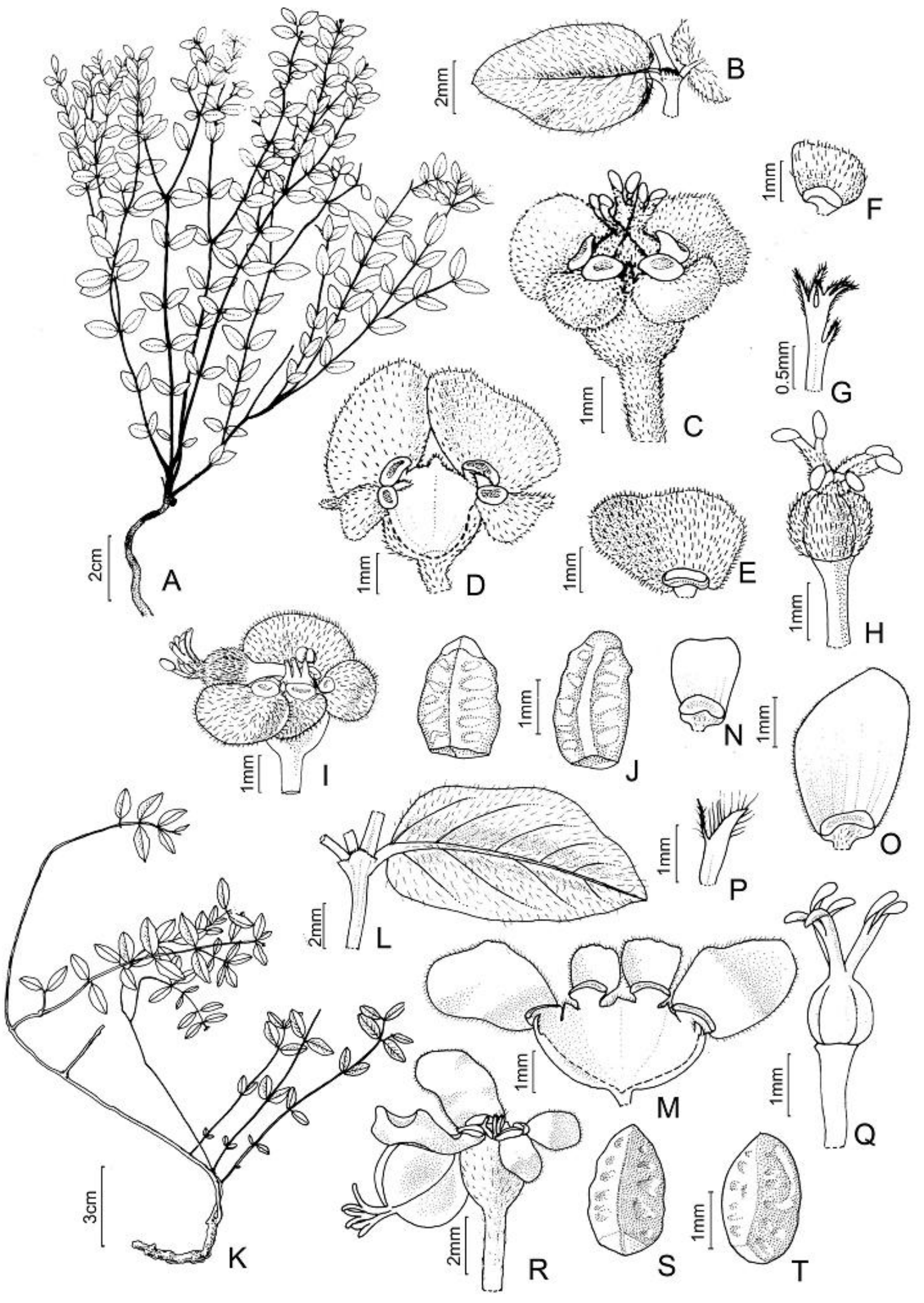

Figura 18. A-J. Euphorbia tamanduana: A- hábito; B- folha e estípula; C- ciátio; D- ciátio, corte longitudinal; E- nectário e apêndice pandurado, vista frontal; F- nectário e apêndice oval, vista frontal; G- bractéola; H- flor pistilada; I- ciátio com fruto; J- sementes, vista lateral (à direita ) e vista dorsal (à esquerda) (Queiroz 5130). K-T. E. viscoides: K- hábito; L- folha e estípula; M- ciátio, corte longitudinal; N- nectário e apêndice obdeltoide, vista frontal; $\mathbf{O}$ - nectário e apêndice pandurado, vista frontal; P- bractéola; Q- flor pistilada; R- ciátio com fruto; S- semente, vista frontal; T- semente, vista lateral (Melo 3085). 
29. Euphorbia viscoides Boiss., Cent. Euphorb.: 4. 1860.

Figuras $18 \mathrm{~K}-\mathrm{T}$ e 19.

Ervas eretas, ca. $30 \mathrm{~cm}$ alt.; ramos esverdeados, esparsa a densamente hirsuto-velutinos a glabrescentes. Folhas opostas, membranáceas; limbo oval-elíptico, 10-17 × 6-7,6 mm, ápice obtuso, base assimétrica, margens inteiras, ciliadas, face abaxial esparsa a densamente pilosa, face adaxial glabra; pecíolo 1-2 $\mathrm{mm}$ compr.; estípulas triangulares, ca. $1 \mathrm{~mm}$ compr., fimbriadas, pilosas. Ciátios zigomorfos, solitários ou em dicásios, axilares; pedúnculos 2-5 $\mathrm{mm}$ compr.; invólucro campanulado ou algumas vezes hemisférico, 1,6-2,5 × 1,5-2,5 mm, hirsuto-velutino externamente, viloso internamente próximo aos nectários; lobos triangulares, margens inteiras, ciliadas, amareloesverdeados; nectários 4, sésseis, transversalmente oblongos, amarelo-esverdeados; apêndices 4, sésseis, desiguais, 2 menores obdeltoide, 2 maiores pandurados, glabros, margens glabras a ciliadas, brancos; bractéolas lineares, vilosas. Flores estaminadas $25-30$ por ciátio, ca. $3,5 \mathrm{~mm}$ compr.; pedicelo $2-2,5 \mathrm{~mm}$ compr. Flores pistiladas ca. $3 \mathrm{~mm}$ compr.; ovário globoso, ca. $1 \times 1 \mathrm{~mm}$, pubescente; estiletes unidos na base, ramos 2-partidos, patentes, glabros; estigmas clavados; pedicelo $1-1,5 \mathrm{~mm}$ compr. Frutos globosos, 2,7-3,6 $\times 3-3,6 \mathrm{~mm}$, hirsutovelutinos, amarelo-esverdeados; pedicelo $2-2,5 \mathrm{~mm}$ compr.; sementes castanho-escuras, subovoides, ca. 1,8 $\times 1,1 \mathrm{~mm}$, ornamentação ausente, sem carúncula.

Referida apenas para Goiás e Minas Gerais (Simmons \& Hayden, 1997), é registrada aqui também para a Bahia. C7, D6/7: campos gerais, sobre solo arenoso. Encontrada com flores ou frutos em março, setembro e novembro.

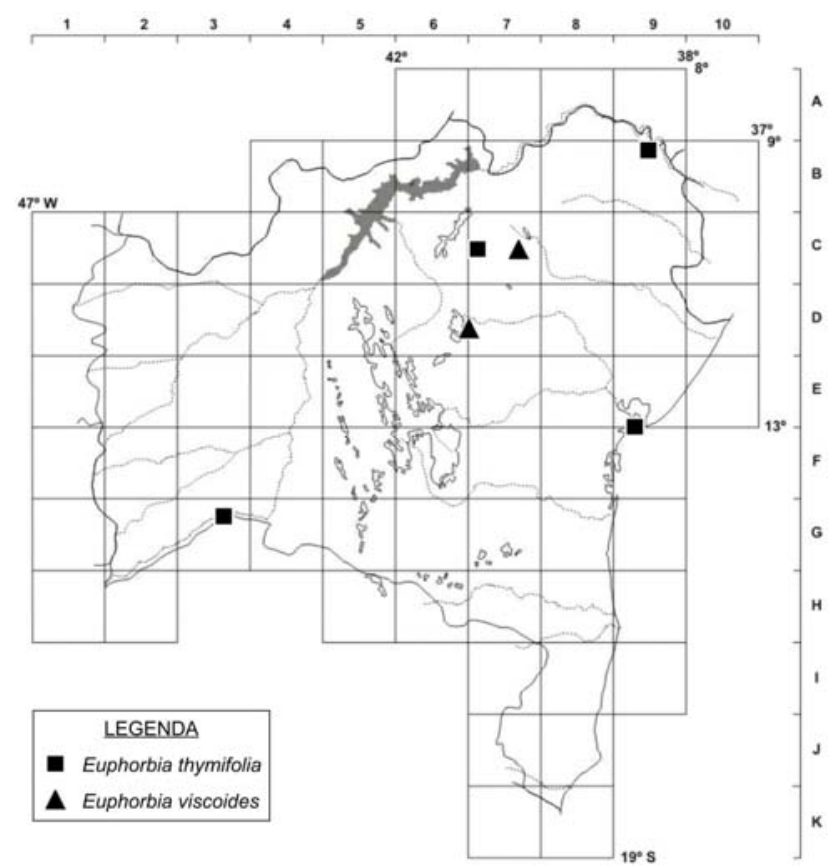

Figura 19 Mapa de distribuição geográfica de Euphorbia thymifolia e E. viscoides no estado da Bahia.
Material selecionado - Campo Formoso, set. 1981, G.C.P. Pinto et al. 327/81 (HRB); Morro do Chapéu, nov. 1999, E. Melo et al.3085 (HUEFS).

Apesar de Müller (1874) ter descrito o invólucro da ciátio como campanulado, o invólucro também pode ser hemisférico, como observado por Simmons \& Hayden (1997) e também neste trabalho. Euphorbia viscoides difere de E. tamanduana e E. potentilloides por apresentar o ciátio zigomorfo e os estiletes glabros, enquanto E. tamanduana possui estiletes crispadopubescentes e $E$. potentilloides tem ciátio actinomorfos.

\section{AgRAdeCIMENTOS}

Agradecemos aos curadores dos herbários, pelo empréstimo do material analisado; ao Dr. Luciano Paganucci de Queiroz, pelas contribuições, e ao Dr. Flávio França, pelas fotos dos tipos. Ao CNPq, pelo financiamento do Projeto Flora da Bahia (483909/2012-2).

\section{REFERÊNCIAS}

BFG (Brazilian Flora Group) 2015. Growing knowledge: an overview of Seed Plant diversity in Brazil. Rodriguésia 66(4): $1-29$.

Chase, M.W.; Zmartzty, S.; Lledó, M.D.; Wurdack, K.J.; Swensen, S.M. \& Fay, M.F. 2002. When in doubt, put it in Flacourtiaceae: a molecular phylogenetic analysis based on plastid $r b c L$ DNA sequences. Kew Bulletin 57: 141-181.

Cordeiro, I. 1995 Euphorbiaceae. In: Brian Stannard. (Orgs), Flora of the Pico das Almas Bahia Brazil. Royal Botanic Gardens, Kew, p. 300-317.

Frodin, D.G. 2004. History and concepts of big plant genera. Taxon 53(3): 753-776.

Horn, J.W.; van EE, B.W.; Morawetz, J.J.; Riina, R.G.; Steinmann, V.W.; Berry, P.E. \& Wurdack, K.J. 2012. Phylogenetics and the evolution of major structural characters in the giant genus Euphorbia L. (Euphorbiaceae). Molecular Phylogenetics and Evolution 63(2): 305-326.

Linnaeus, C. 1753. Euphorbiaceae. In: Species Plantarum. Vol. 1. Ray Society, London, tab. 3.

Lucena, M.F.A. \& Alves, M. 2010. Notas taxonômicas para Euphorbiaceae s.l. do Nordeste do Brasil. Hoehnea 37(1): 7185.

Müller, J. 1874. Euphorbiaceae. In: C.F.P. Martius \& A.G. Eichler (eds), Flora Brasiliensis. Vol. 11, pars 2. Typographia Regia, Monachii, p. 1-752.

Oliveira, A.S. \& Sá-Haiad, B. 1988. Estudos taxonômicos sobre a família Euphorbiaceae Juss. - I: Euphorbia heterophylla L. e Euphorbia cyathophora Murr. Sellowia 40: 5-31.

Radcliffe-Smith, A. 2001. Genera Euphorbiaceaerum. Kew Publishing, Kew.

Rizzini, C.T. 1989. Cactiform species of Euphorbia from Brazil (Euphorbiaceae). Revista Brasileira de Biologia 49(4): 979997. 
Silva, O.L.M.; Cordeiro, I. \& Caruzo, M.B.R. 2014. Synopsis of Euphorbia (Euphorbiaceae) in the state of São Paulo, Brazil. Phytotaxa 181(4): 193-215.

Simmons, M.P. \& Hayden, W.J. 1997. Revision of the cerrado hemicryptophytic Chamasyce of Boissier's "Pleiadeniae" (Euphorbiaceae). Brittonia 49: 155-180.

Steinmann, V.W. \& Porter, J.M. 2002. Phylogenetic relationships in Euphorbieae (Euphorbiaceae) based on ITS and $n d h \mathrm{~F}$ sequence data. Annals of the Missouri Botanical Garden 89: 453-490.

Subils, R. 1977. Las especies de Euphorbia de la Republica Argentina. Kurtziana 10: 83-248.

Ule, E. 1908. Beiträge zur Flora von Bahia I. Botanische Jahrbürcher fur Systematik, Pflanzengeschichte und Pflanzengeographie 42: 191-238.
Webster, G.L. 1994a. Synopsis of the genera and suprageneric taxa of Euphorbiaceae. Annals of the Missouri Botanical Garden 81(1): 33-144.

Webster, G.L. 1994b. Classification of the Euphorbiaceae. Annals of the Missouri Botanical Garden 81(1): 3-32.

Wurdack, K.J. \& Davis, C.C. 2009. Malpighiales phylogenetics: gaining ground on one of the most recalcitrant clades in the angiosperm tree of life. American Journal of Botany 96(8): 1551-1570.

Wurdack, K.J.; Hoffmann, P. \& Chase, M.W. 2005. Molecular phylogenetic analysis of uniovulate Euphorbiaceae (Euphorbiaceae sensu stricto) using plastid $r b c L$ and $\operatorname{trnL}-F$ DNA sequences. American Journal of Botany. 92: 1397-1420.

\section{LISTA DE EXSICATAS}

Almeida-Silva, G. 103 (24), Alves, M. EBNN 936 (12), EBNN 1241 (20), EBNN 1259 (8), EBNN 1387 (20); Amorim, D.G. 6 (16); Andrade-Lima, D. 614670, s.n. ALCB 2167 (19); Arbo, M.M. 7229 (24); 7248 (7), 7480 (6); Arouck, J. 185 (7); Atkins S. PCD 5086 (7); Bandeira, F.P. 210 (1); Barroso, G. s.n. ALCB 19800 (24). Bastos, B.C. 437, 458 (7); Bastos, C.A. 45 (22); Bautista, H.P. 386 (16), 502 (14), PCD 3216 (24), PCD 3416 (3), PCD 4325 (20); Borba, E.L. 2042 (19); Britto, K.R.B. 13 (7), 184 (19), 263 (13); Cardoso, D. 911 (1), 1813 (7), 885 (19), 2544 (29); Carneiro-Torres, D.S. 53 (3), 136 (11), 137 (12), 172 (24), 173 (22), 174 (13), 185 (16), 205 (20), 210 (8), 211 (14), 214 (15), 221 (13), 249 (20), 513 (19), 525 (13), 900, 906 (26), 909 (11), 912 (26), 980 (19), 1005 (10); Caruzo, M.B.R. 130 (12), 133 (24), 136 (26), 136 (29), 139 (11), 141 (22), 142 (13), 147 (26), 148 (24); Carvalho, A.M. 708 (12), 1535 (13), 1595,1689 (7); 2428 (19), 2672 (7), 2848 (3); Carvalho, D.N. 279 (1); Carvalho, P.D. 147 (1), 245 (7), 342 (20), 456 (16), 457 (1); Carvalho-Sobrinho, J.G. 516 (15); Cerqueira-Filho, F.M. s.n. HUEFS 42408 (7); Colaço, M. 104 (16); Conceição, A.A. 1700 (20), 2680 (16), 3034 (13), 3109 (7), 3249 (20); Conceição, S.F. 429 (16); Coradin, L. 2953 (16); Correia, C. 405 (20), 425 (13); Cordeiro, I. 2203 (10), 2204 (19), 2216 (3), 2218 (24), 2233 (22), 2234 (13), 2251 (12), 3389 (24), 3398 (24); Costa, J. 120 (25), 121 (14); Costa-Neto, E.M. 13 (16); Eggli, U. 1275 (11); Ferreira, C. 424 (14); Ferreira, J.L. 317 (13). Ferreira, M.C. 410 (16), 1292 (19); Fonseca, W. 322 (19); Forzza, R.C. 1289 (3); França, F. 1057 (17), 1401, 1597 (19), 1602 (9), 1729 (16), 1940 (13), 2151 (10), 2168 (7), 2182 (13), 2302 (1), 2413 (10), 2789 (3), 2816 (24), 2819 (20), 2829 (10), 2865 (19), 3145 (13), 3237 (16), 4064 (3), 4083 (11), 4094 (19), 4114 (29), 4281 (20), 4332 (22), 4361 , 4691 (11), 4814 (13), 4959 (23), 5137 (19), 5332 (15), 5752 (1); Freitas, I.S. 14 (20); Freitas, J.G. 10 (16), 75 (15); Freitas, M. 22 (22); Fonseca, M.R. 1324(1); Fonseca, W. 322 (19); Fotius, G. 3350, 3969 (28), 4019(2), 4076 (22), 5752 (2); Funch, R. 389 (20), 527 (24), 1511 (20); Ganev, W. 387 (15), 1006 (20), 2028 (8); Gasson, P. PCD 5936 (3); Giulietti, A.M. 1495 (8), 1553 (20), 1723 (1), 2117,2417 (8), PCD 3266 (11), PCD 3267 (3), PCD 3268 (19); Gonçalves, J. M. 207 (22); Gonçalves, L.M.C. 204 (7); Grupo Pedra do Cavalo 13 (16), 30 (15), 134 (16), 139 (1), 151 (7), 454 (17), 620 (16), 669, 821 (17); Guedes, L.M. PCD 1459, PCD 1966, PCD 2037 (20), PCD 2723 (10), PCD 3021 (2), PCD 5273 (7), PCD 5739 (9), 15763, 15911 (14); Haje, J.: 1855 (16); Harley, R.M.: PCD 3404, 15023 (7), 15684 (12), 15720 (20), 15721 (24), 16379 (7), 16419 (13), 16487 (9), 16580, 16585 (17), 16623 (16), 16665 (11), 16831 (26), 16887 (14), 16960 (19), 17011 (3), 17461 (15), 18980 (6), 19202 (3), 19331 (29), 19423 (19), 19937 (20), 20888 (12), 21153 (20), 21602 (7), 22752,22868 (3), 22872 (16), 25691 (8), 25979, 26010, 26287 (20), 26969 (24), 27386 (3), 28451 (7), 50169, H50356 (20), 53406 (14), 53492 (17), 53543 (24), 53684 (17), 53789 (23), 53891 (11), 53964 (8), 55035 (23), 54587 (1), 55759 (16); Hatschbach, G. 47012 (17), 48193 (19); Hind, D.J.N. PCD 3148 (1), PCD 4063 (20), PCD 4128 (24), H50011 (16); Hurbath, F. 410 (4), 510, 580 (4); Irwin, H.S. 32661 (22); Jardim, J.G. 3420 (1), 3474 (19), 3595 (28); Jesus, N.G. 384 (16), 518 (15), 530 (17), 1557, 1833 (5); Kral, R. 72752 (8); Lemos, M.J.S. 10 (16), 176 (3); Leite, K.R.B. 184 (19), 263 (13); Lima, E.B. 10, 11 (14); Kral, R. 72752 (8); Machado, A.F.P. 1221 (19); Machado, M. 77,145 (20), 196, 226 (22), 772 (27), 778 (13); Machado, R.F. 127 (18), 206 (16); Marinho, L. 402 (19); Martinelli, G. 6644 (13); Mattos-Silva, L.A. 54 (14), 278 (7), 2067 (16), 2376 (14), 3166 (15), 3299 (15), 3599 (14); Mayo, J. 1209 (20); Medeiros-Neto, E.C. 13 (16); Melo, E. 1173 (19), 1617, 2835,2899 (16), 2996 (25), 3085 (29), 3230 (14), 3443, 3444 (29), 3461 (10), 3640 (18), 3911, 4126 (13), 4585 (19), 4713 (22), 5165 (7), 5246 (29), 5350 (18), 7019 (21), 7247, 7256 (19), 9422 (21), 9568 (14), 8509 (3), 11269 (13), 11525 (9), 11681,11860 (13), 12330 (11); Miranda, A.M. 2874 (25), 4190 (20), 4265 (10); Miranda, E.B. 4 (10), 526 (20), 842 (13), 961 (16); Miranda-Silva, E.B. 165 (16), 224 (19), 265 (20), 315 (7), 545 (8), 4265 (3); Moraes, A.O. 312 (13); Moraes, M.V. 497 (28), 543 (9), 798 (14); Mori, E. 10536 (17); Mori, S.A. 9855 (16), 9862 (15), 11797 (13); Nascimento, A. 242 (1); Neves, S.P.S. 208 (20); Noblick, L.R. 1650 (13), 1683 (1), 1939 , 1949 (15), 1999 (17), 2466 (16), 2556 (1), 2557, 2610 (15), 2617 (16), 2936 (14), 2988 (15), 2993 (21), 3028 (16), 3040 (14), 3194 (17), 3493 (24), 3531 (3), 3684 (7), 3850 (15), 3913 (21), 3928 (14), 4037 (16), 4089 (7), 4152, 4177 (1), 4214 (16), 4231 (7), 4327 (16), 4342 (17), 4503 (16); Nonato, F.R. 958 (11); Nunes, T.S. 332 (16), 1484 (24); Oliveira, R.P. 48 (20), 75 (29), 76 (20), 89 (19), 272 (7), 347 (16), 647 (8), 670 (5), 671, 674 (5), 736 (14), 809 (3), 646, 949, 1015 (20), 1294 (11), 1328 (26), 2016 (24); Orlandi, R.P. 294 (7), 326 (22); Pinto, G.C.P. 03/90 (21), 31/92 (16), 327/81 (29), 383/83A (3), s.n. ALCB 19880 (24); Pirani, J.R. 4957 (16), CFCR 2163 (20); Popovkin, A.V. 15 (7), 536 (14), 537 (16); Portugal, S. 4 (5); Queiroz, E.P. 2918(12); Queiroz, L.P. 387(13), 739(19), 848(12), 1255(3), 14663(2), 1524 (7), 1636 (19), 1748 (7), 2548 (12), 3110 (19), 3299 (13), 4036, 4277 (3), 4796 (2), 5130 (26), 5196 (11), 5853 (13), 5895 (17), 6009 
(7), 7732 (22), 7888 (6), 9016, 9128 (1), 9717 (16), 10595 (7), 10611 (23), 12207 (13), 14879 (11), PCD 3943 (20), PCD 3947 (24); Ramos, M.M. 3 (12); Rapini, A. 1523 (20); Ribeiro, P.L. 252 (24); Roque, N. PCD 2262 (19); Saar, E. 12 (19); Salino, A. 3073 (23); Santos, A.K.A. 716 (24); Santos, B.T.C. 329 (23); Santos, E.P. 228 (20); Santos, J.M. 1324, s.n. HUEFS 45308 (7); Santos, T.S. 1626 , 3607 (7); Santos, V.J. 508 (16), 483 (14); Senna, L. 150 (1); Silva, B.M. 5 (17); Silva, M. 25 (1); Silva-Castro, M.M. 236, 295,317 (16), 341 (7), 360 (16), 548 (7); Souza, V.C. 26327, 26357 (11); Stannard, B. PCD 4810, PCD 5745 (20); Taylor, N. 1563, 1578, 1609 (7); Thomas, W. 11949 (7); van den Berg, C. 927 (10); Viana, B.F. 19 (12); Wanderley, M.G.L. 886 (8); Webster, G.L. 25078 (16), 25147 (13), 25818 (7); Woodgyer, E. PCD 2556 (22). 